\title{
Combined Action of Copper with IAA on Individual Amino Acids and Microelement in Pods of Two Broad Bean Cultivars
}

\author{
Hamdia Mahmoud Abd El-Samad1*, Mohamed Abdo Kheder Shaddad², Khloud Nagy Shaker ${ }^{2}$ \\ ${ }^{1}$ Botany Department and Microbiology, Faculty of Science, Minia University, El-Minia, Egypt \\ ${ }^{2}$ Botany Department, Faculty of Science, Assiut University, Assiut, Egypt \\ Email: `hamdia10@yahoo.com
}

How to cite this paper: El-Samad, H.M.A., Shaddad, M.A.K. and Shaker, K.N. (2019) Combined Action of Copper with IAA on Individual Amino Acids and Microelement in Pods of Two Broad Bean Cultivars. American Journal of Plant Sciences, 10, 670-697.

https://doi.org/10.4236/ajps.2019.104049

Received: March 11, 2019

Accepted: April 26, 2019

Published: April 29, 2019

Copyright $\odot 2019$ by author(s) and Scientific Research Publishing Inc. This work is licensed under the Creative Commons Attribution International License (CC BY 4.0).

http://creativecommons.org/licenses/by/4.0/

\begin{abstract}
It is worthy to mention that the two broad bean cultivars displayed a surprising situation during the fruiting stage of growth. The absolute amount of pods yield was higher in $\mathrm{cv}$. Assiut 125 than in $\mathrm{cv}$. Assiut 84 . This situation was in contrast with that in the vegetative stage, where cv. Assiut 84 produced greater vegetative growth than cv. Assiut 125. Although the cv. Assiut 84 was less affected by the highest dose of copper, the cv. Assiut 125 was greatly affected by this dose. However, another surprising situation was recorded when the absolute values of fresh and dry matter of $\mathrm{cv}$. Assiut 125 were much higher than cv. Assiut 84 at any used copper concentration. The fresh matters of the pods of cv. Assiut 84 and cv. Assiut 125 were 7.24 and $10.16 \mathrm{gm}$ at the level of control and 6.69 and $7.59 \mathrm{gm}$ at the level of $350 \mathrm{ppm} \mathrm{Cu}$, respectively. Their dry matters were 1.99 and $3.52 \mathrm{gm}$ at the level of control and 1.77 and $2.13 \mathrm{gm}$ at the level of $350 \mathrm{ppm} \mathrm{Cu}^{2+}$ in cv. Assiut 84 and cv. Assiut 125, respectively. This contradiction was also extended when these copper-affected cultivars were sprayed by IAA. The cv. Assiut 84 responded slightly to IAA treatment. On the other hand, a considerable increase in the dry matter yield was recorded in the pods of cv. Assiut 125 at any used level of copper when compared to the non-sprayed plants treated by the same copper concentration. At the level of $350 \mathrm{ppm} \mathrm{Cu}^{2+}$, the pod yield was 2 -fold that of plants treated only by $350 \mathrm{ppm} \mathrm{Cu}{ }^{2+}$, without IAA spraying. Thus, even IAA behaved differently in its effect on the crop yield of the two tested broad bean cultivars. There are big and surprising variations in the accumulation of microelements and heavy metals in pods among the two broad bean genotypes, whatever the treatments used. These variations seemed to be complicated which might need further studies. The concentration of amino acids and their individuals also varied among the two cultivars; they increased in cv. Assiut 84 and decreased in cv. Assiut 125. The increased amino acids in cv. Assiut 84
\end{abstract}


are mostly used as precursors for phytochelatins. For the previous studies, thus the present work was conducted to explain the effect of $\mathrm{Cu}$ and interactive effect with IAA on two selected broad bean cultivars Assiut 84 and Assiut 125 during yielding production.

\section{Keywords}

Synergistic Effect, Amino Acids, Microelement, Broad Bean Cultivars

\section{Introduction}

Essential micronutrients are required in low concentrations, so that the plant can develop normally, but are toxic in high concentrations [1] [2]. Copper $(\mathrm{Cu})$ has been considered to be an essential micronutrient for plants; it is an element of vital importance in seed production, disease resistance, and balance of water catchment [1] [3] and of other essential nutrients, that depend on copper solubility in the soil and the type of soil [4] [5] [6]. Scientists have been more interested in developing potential strategies to promote germination of seeds, growth of plants and higher crop production [7] [8] [9]. This goal is getting even more needed to alleviate the adverse effects of environmental pollutants, and the search for molecules mediating stress tolerance is a relevant step toward a better understanding of how lower plants respond to stress [10]. In particular IAA increased root and sometimes also shoot growth of plants that were stressed by salinity or heavy metals [11] [12] [13] [14] [15]. Diaz et al. (2017) [16] provide information about copper tolerance mechanisms. We evaluated the effect of copper (II) ions (control, 100 and $500 \mu \mathrm{M}$ ) on C. quitens seedlings in vitro, determining morpho-physiological and biochemical variables. Copper showed a significantly negative effect on the development of new shoots $(500 \mu \mathrm{M})$ and floral apex appearance $(100 \mu \mathrm{M})$. The highest proline accumulation took place in seedlings subjected to $500 \mu \mathrm{M}$. Hamdia et al. (2018) [6] observed that when the copper stressed plants sprayed with IAA where a lot of these cations were transported in the same trend from the soil solution into the different parts of the two broad bean plants without any competition among these cations. The uptake, translocation and distribution of mineral ions are affected by various growth regulators among others by IAA. Massoud et al. (2018) [17] compare the efficiency of two types of treatments with the exogenous effectors (IAA, GA3, Ca and citric acid) against copper ( $\mathrm{Cu}$ ) toxicity: 1) the simultaneous application of " $\mathrm{Cu}^{++}$effectors" at the beginning of germination (day 0) and 2) the abruption of $\mathrm{Cu}$ stress (exogenous effectors are added in the third day). Thus, this investigation was carried out to study the mechanisms of combined action of copper with IAA treatments on individual amino acids and microelements in pods of two broad bean plants.

\section{Materials and Methods}

\subsection{Experimental Sites and Copper Treatments}

Broad bean seeds cv. Assiut 84 and Assiut 125 were obtained from one of the ac- 
tive breading programs directed by Prof. Dr. Esmat Waly and Prof. Dr. Saeyd Abdellah, Faculty of Agriculture, Assiut University, Egypt. Broad bean plant is important economic crop plant and consider the first plant food for Egyptian people because it contains highly benefit protein and other essential elements for man healthy. Which has several common names (broad bean, fava bean, faba bean, horse bean, field bean, tick bean), is a species of bean (Fabaceae) native to North Africa and southwest Asia and is extensively cultivated elsewhere. In much of the world, the name broad bean is used for the large-seeded cultivars grown for human food. In Egypt, faba bean is the most common fast food item in the Egyptian diet, eaten by rich and poor alike. Egyptians eat faba beans in various ways; the most popular way of preparing faba beans is taking cooked beans, mashing them and adding oil, lemon, salt and cumin. The prepared beans, called fulmedames, are then eaten with bread. Faba bean is an excellent source of protein $(20 \%-25 \%)$, calcium $(0.15 \%)$, phosphorus $(0.50 \%)$, lysine (1.5\%) and methionine-cystine $(0.5 \%)$ in dry weight. It is also an excellent source of complex carbohydrates, dietary fiber, choline, lecithin, minerals and secondary metabolites (phenolics and levodihydroxy phenylalanine (L-DOPA), which is the precursor of the neurotransmitter dopamine and naturally found in seedlings, green pods and beans) [18] [19]. Broad bean seeds (cv Assiut 84 and Assiut 125) were obtained from one of the active breading programs directed by Prof. Dr. Esmat Waly and Prof. Dr. Saeyd Abdellah, Faculty of Agriculture, Assiut University, Egypt. From previous work Hamdia et al. (2018) [6] stated that at vegetative stage in cv. Assiut 84 the dry matter of stems and leaves increased as copper increased in the soil up to $200 \mathrm{ppm}$, then while a slight stimulation was obtained in leaves (about 4\%), a slight reduction was recorded in stems (20\%). The dry matter of roots remained more or less unchanged up to $200 \mathrm{ppm} \mathrm{Cu}$, then about $24 \%$ reduction was recorded, which means that the three plant organs responded differently to copper treatments. In cv. Assiut 125 the dry matter of pods increased by copper treatment up to $200 \mathrm{ppm}$, which was more pronounced in leaves, then a highly significant reduction was recorded (about 30\% in both). In roots, a gradual reduction was exhibited by increasing the copper concentration in the soil. This inhibitory effect was more obvious at the level of $350 \mathrm{ppm} \mathrm{Cu}$ (about 40\% reduction). Broad bean seeds were surface sterilized by immersion in a mixture of ethanol $96 \%$ and $\mathrm{H}_{2} \mathrm{O}_{2}$ (1:1) for 3 minutes, followed by several washings with sterile distilled water. The concentrations of copper were chosen after preliminary experiments in which the seeds were subjected to different concentrations of copper. The chosen concentrations caused slight stimulation and moderate inhibition of seed germination from $100 \mathrm{ppm}$ to 350 ppm copper treatment were recorded. Copper was added as copper sulphate $\left(\mathrm{CuSO}_{4}\right)$. Ten seeds were sown per pot, each pot contained $3.6 \mathrm{~kg}$ of garden clay soil. The clay soil comprise four components minerals and soil organic matter make up the solid fraction, whereas air and water comprise the pore space fraction. A typical agricultural soil is usually around 50\% solid particles and 50\% pores (Adapted from Brady and Weil, 2002 [20]). Soil particle of clay is $<0.002$ 
invisible to naked eye. Considerations of working in controlled environments were followed by Tibbitts \& Langhans (1993) [21]. All pots were irrigated with tap water for four weeks until full germination. In preliminary experiments explained that low concentration is $100 \mathrm{ppm} \mathrm{CuSo}_{4}$ and the high concentration is $350 \mathrm{ppm}$. The seedlings were then irrigated by different concentrations of $\mathrm{CuSO}_{4}$ solutions $(0,100,200,350 \mathrm{ppm})$ and were classified into two groups.

\subsection{Copper Treatment and Combined with IAA}

From two of previous groups which treated with different copper concentration $(0,100,200,350 \mathrm{ppm})$, one group was sprayed by $200 \mathrm{ppm}$ IAA. In order to maintain the osmotic potential, the soil moisture content was kept near the field capacity using tap water. The seedlings were left to grow in natural conditions under these conditions for 150 days. At the end of the experimental period (5 months) yields of pods determined.

\subsection{Laboratory Analysis for Metabolites}

To determine the dry matter yields of pods were dried in an oven at $80^{\circ} \mathrm{C}$. Successive weighing was carried out until the constant dry weight of each sample was reached. The soluble carbohydrates were determined by the method of anthrone sulphoric acid which was stated by Fales (1951) [22]. The soluble proteins were determined according to the method adopted by Lowery et al. (1951) [23]. Calcium and magnesium determination by Schwarzenbach and Biedermann, (1948) [24] was employed. Potassium, Flamephotometer method using Carl Zeiss flamephotometer was used by Williams and Twine, (1960) [25].

\section{Statistical Analysis}

The triplicate sets of the experimental data for the different tested parameters were subjected to the one way analysis of variances (ANOVA) test in accordance with the experimental design using the SPSS program, version 13.0 and the means were compared using the least significant differences, L. S. D. at $0.05 \%$ levels [26].

\section{Results}

In cv. Assiut 84 the fresh and dry weights of pods increased progressively by increasing $\mathrm{Cu}$ concentration in the soil up to the level of $200 \mathrm{ppm}$. At this level, the percent of increase in fresh and dry matters was $40.6 \%$ and $33.7 \%$ over the control value, respectively. However, the fresh and dry matters of pods of cv. Assiut 84 reduced slightly at the concentration of $350 \mathrm{ppm} \mathrm{Cu}$. The percent of reduction did not exceed $7.67 \%$ and $10.95 \%$ in fresh and dry matters, respectively. In cv. Asiut 125 the copper up to the level of $100 \mathrm{ppm}$ induced an increase in fresh and dry matter yields (36.2\% and 3.04\%, respectively). Then a slight reduction was exhibited up to $200 \mathrm{ppm} \mathrm{Cu}^{2+}$ and a highly significant reduction was ob-

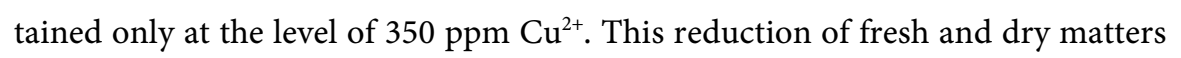


of pods was $25.3 \%$ and $39.4 \%$, respectively, as compared to the control values. The various levels of $\mathrm{Cu}^{2+}$ considerably increased the soluble carbohydrates contents of pods of the broad bean cultivar Assiut 84 . The highest accumulation was obtained at the level of $200 \mathrm{ppm} \mathrm{Cu}$. At this level, the percent of increase was $42.78 \%$. In cv. Assiut 125, the soluble carbohydrates in pods were stimulated up to the level of $200 \mathrm{ppm} \mathrm{Cu}^{2+}$, and then a highly significant reduction in this fraction was recorded. In cv. Assiut 84 the soluble proteins remained more or less unchanged by the various concentrations of $\mathrm{Cu}^{2+}$. The induction of $\mathrm{Cu}^{2+}$ on the accumulation of proteins in pods of cv. Assiut 125 went opposite to that in $\mathrm{cv}$. Assiut 84 , the soluble fraction decreased progressively. Potassium remained mostly unchanged at any concentration of $\mathrm{Cu}^{2+}$. Some reduction was recorded at the higher dose of $\mathrm{Cu}^{2+}$ (15\% reduction) in cv. Assiut 84 (Tables 1-3). A slight promotion in $\mathrm{K}^{+}$contents was revealed in pods of cv. Assiut 125 as a result of the various treatments by $\mathrm{Cu}^{2+}$ (Table 3). In Cv. Assiut 84 calcium content in the pods of cv. Assiut 84 decreased slightly up to $200 \mathrm{ppm} \mathrm{Cu}^{2+}$. This reduction was constant at the two copper levels 100 and 200 ppm (14.29\%). Then, a highly significant reduction was recorded only at the level of $250 \mathrm{ppm} \mathrm{Cu}^{2+}$ (42.86\% of control). Pods of cv. Assiut 125 were able to maintain their $\mathrm{Ca}^{++}$content at the level of control values at any used $\mathrm{Cu}$ level (the amount of $\mathrm{Ca}^{++}$was $5 \mathrm{mg} / \mathrm{gm}$ dry weight at all levels of $\mathrm{Cu}$ ). $\mathrm{Cu}$ treatments irregularly accumulated magnesium in pods of $\mathrm{cv}$. Assiut 84 at any used level of $\mathrm{Cu}$. It was $275 \%$ of control at the level of 100 and 350 ppm $\mathrm{Cu}$ and $225 \%$ at the level of $200 \mathrm{ppm} \mathrm{Cu}$ (Table 3). Irregular data of magnesium content in pods of cv. Assiut 125 were exhibited by the various levels of copper (Table 3). Magnesium content remained unchanged at the levels of $100 \mathrm{ppm}$ and $350 \mathrm{ppm} \mathrm{Cu}$ and increased by $75 \%$ at the level of $200 \mathrm{ppm} \mathrm{Cu}$.

\subsection{Interaction with Phytohormone IAA}

A marked and progressive accumulation of fresh and dry matter yields was exhibited as a result of IAA treatments whatever the concentration of $\mathrm{Cu}$ used in cv. Assiut 84 . IAA increased the fresh and dry matter in pods by $28.59 \%$ and $15.27 \%$ at the level of $350 \mathrm{ppm} \mathrm{Cu}$, the maximum value was recorded at $200 \mathrm{ppm}$ $\mathrm{Cu}$ treatment. Phytohormonal treatments resulted in a considerable accumulation of the fresh and dry matters in pods that reached $54.34 \%$ and $22.31 \%$ over the control values, respectively in cv. Assiut 125, the maximum value was obtained at $100 \mathrm{ppm} \mathrm{Cu}$ treatment. In cv. Assiut 84 IAA treatments unchanged soluble cabohydrated content except at $350 \mathrm{ppm}$ an increase was exhibited as compared with control plants. In cv. Assiut 125 an additional increase in the accumulation of carbohydrates was recorded as a result of IAA treatments. A marked and progressive accumulation of soluble proteins was recorded as a result of IAA treatments in cv. Assiut 84. IAA treatments induced a considerable accumulation in proteins of $\mathrm{cv}$. Assiut 125 pods whatever the concentration of $\mathrm{Cu}^{2+}$ used. Some promotion in $\mathrm{K}$ content was exhibited by IAA treatments in pods of $\mathrm{cv}$. Assiut 84 . This promotion was higher at the lowest dose of $\mathrm{Cu}$. In $\mathrm{cv}$. 
Table 1. Effect of $\mathrm{CuSO}_{4}$ and $\mathrm{CuSO}_{4}$ plus IAA on the fresh and dry matter yields in pods of the broad bean cultivars Assiut 84 and Assiut 125.

\begin{tabular}{|c|c|c|c|c|c|c|c|c|c|}
\hline \multirow{2}{*}{ Treatment } & \multirow{2}{*}{$\begin{array}{l}\mathrm{CuSO}_{4} \\
(\mathrm{ppm})\end{array}$} & \multicolumn{4}{|c|}{ Cv. Assiut 84} & \multicolumn{4}{|c|}{ Cv. Assiut 125} \\
\hline & & F. m. & $\%$ & D. $\mathrm{m}$. & $\%$ & F. m. & $\%$ & D. $\mathrm{m}$. & $\%$ \\
\hline \multirow[t]{2}{*}{$\begin{array}{c}\text { Absolute } \\
\text { control }\end{array}$} & 0 & 7.24 & 100 & 1.99 & 100 & 10.16 & 100 & 3.52 & 100 \\
\hline & 100 & 8.04 & 111.09 & 2.48 & 124.46 & $13.84^{\star *}$ & 136.20 & 3.63 & 103.04 \\
\hline \multirow[t]{4}{*}{$\mathrm{CuSO}_{4}$} & 200 & $10.18^{* *}$ & 140.61 & $2.66^{*}$ & 133.70 & 9.24 & 90.96 & 2.99 & 84.91 \\
\hline & 350 & 6.69 & 92.33 & 1.77 & 89.05 & $7.59^{\star \star}$ & 74.71 & $2.13^{\star *}$ & 60.63 \\
\hline & 0 & $11.18^{\star *}$ & 154.41 & 2.33 & 117.23 & $16.21^{\star *}$ & 159.58 & 4.01 & 113.96 \\
\hline & 100 & $12.05^{\star *}$ & 166.37 & $2.89^{\star *}$ & 144.95 & $19.01^{\star *}$ & 187.13 & $4.89^{\star *}$ & 138.94 \\
\hline \multirow{2}{*}{$\mathrm{CuSO}_{4}+\mathrm{IAA}^{-}$} & 200 & $12.39^{\star *}$ & 171.13 & $2.82^{\star *}$ & 141.44 & $16.34^{* *}$ & 160.90 & $4.71^{\star *}$ & 133.83 \\
\hline & 350 & $9.31^{* *}$ & 128.59 & 2.30 & 115.27 & $15.68^{\star *}$ & 154.34 & $4.30^{*}$ & 122.31 \\
\hline L. S. D. $0.05 \%$ & & 1.01 & & 0.47 & & 0.83 & & 0.53 & \\
\hline
\end{tabular}

*Significant differences and ${ }^{* *}$ highly significant differences as compared to the absolute control.

Table 2. The effect of $\mathrm{CuSO}_{4}$ and $\mathrm{CuSO}_{4}$ plus IAA treatments on soluble carbohydrates $\left(\mathrm{mg} \cdot \mathrm{gm}^{-1} \cdot \mathrm{d} \cdot \mathrm{m}.\right)$ and soluble proteins $\left(\mathrm{mg} \cdot \mathrm{gm}^{-1} \cdot \mathrm{d} \cdot \mathrm{m}.\right)$ in the pods of the broad bean cultivars Assiut 84 and Assiut 125.

\begin{tabular}{|c|c|c|c|c|c|}
\hline Treatment & $\mathrm{CuSO}_{4}(\mathrm{ppm})$ & Sol. Carb. & $\%$ & Sol. Pro. & $\%$ \\
\hline \multirow[t]{2}{*}{ cv. Assiut 84} & 0 & 10.74 & 100 & 59.70 & 100 \\
\hline & 100 & $12.10^{*}$ & 112.66 & 55.97 & 93.75 \\
\hline \multirow[t]{3}{*}{$\mathrm{CuSO}_{4}$} & 200 & $15.33^{* *}$ & 142.78 & $53.73^{*}$ & 90.00 \\
\hline & 350 & $13.71^{\star *}$ & 127.72 & $47.39^{\star *}$ & 79.37 \\
\hline & 0 & 9.83 & 91.57 & $139.42^{\star *}$ & 233.54 \\
\hline \multirow{3}{*}{$\mathrm{CuSO}_{4}+\mathrm{IAA}$} & 100 & 10.74 & 100 & $184.04^{\star *}$ & 308.27 \\
\hline & 200 & 11.64 & 108.44 & $166.35^{\star *}$ & 278.63 \\
\hline & 350 & $14.68^{* *}$ & 136.75 & $162.89^{\star *}$ & 272.83 \\
\hline L. S. D. $0.05 \%$ & & 0.84 & & 0.39 & \\
\hline \multirow[t]{2}{*}{ cv. Assiut 125} & 0 & 6.68 & 100 & 46.27 & 100 \\
\hline & 100 & 7.12 & 106.53 & $41.42^{* *}$ & 89.52 \\
\hline \multirow[t]{3}{*}{$\mathrm{CuSO}_{4}$} & 200 & $7.89^{\star *}$ & 118.15 & $40.30^{* *}$ & 87.10 \\
\hline & 350 & $5.11^{* *}$ & 76.51 & $39.54^{* *}$ & 85.45 \\
\hline & 0 & $11.26^{* *}$ & 168.51 & $139.42^{* *}$ & 301.33 \\
\hline \multirow{3}{*}{$\mathrm{CuSO}_{4}+\mathrm{IAA}$} & 100 & $13.39^{* *}$ & 200.48 & $113.08^{\star \star}$ & 244.39 \\
\hline & 200 & $15.85^{\star *}$ & 237.27 & $118.85^{\star *}$ & 256.86 \\
\hline & 350 & $9.51^{\star *}$ & 142.36 & $93.65^{\star *}$ & 202.41 \\
\hline L. S. D. $0.05 \%$ & L. S. D. $0.05 \%$ & 0.83 & & 0.28 & \\
\hline
\end{tabular}

${ }^{*}$ Significant differences and ${ }^{*}$ highly significant differences as compared to the absolute control. 
Table 3. Effect of $\mathrm{CuSO}_{4}$ and $\mathrm{CuSO}_{4}$ plus IAA treatments on $\left(\mathrm{mg} \cdot \mathrm{gm}^{-1} \cdot \mathrm{d} \cdot \mathrm{m}\right.$.) in pods of the broad bean cultivars Assiut 84 and Assiut 125.

\begin{tabular}{|c|c|c|c|c|c|c|c|}
\hline Treatment & $\mathrm{CuSO}_{4}(\mathrm{ppm})$ & $\mathrm{K}^{+}$ & $\%$ & $\mathrm{Ca}^{2+}$ & $\%$ & $\mathrm{Mg}^{2+}$ & $\%$ \\
\hline \multirow[t]{2}{*}{ cv. Assiut 84} & 0 & 12 & 100 & 5.25 & 100 & 1.8 & 100 \\
\hline & 100 & 11.5 & 95.83 & $4.5^{\star}$ & 85.71 & $4.95^{\star *}$ & 275 \\
\hline \multirow[t]{3}{*}{$\mathrm{CuSO}_{4}$} & 200 & 10.6 & 88.33 & $4.5^{*}$ & 85.71 & $4.95^{\star *}$ & 275 \\
\hline & 350 & 10.2 & 85.00 & $3.0^{* *}$ & 57.14 & $4.05^{* *}$ & 225 \\
\hline & 0 & 11.9 & 99.17 & 5.5 & 104.76 & $8.1^{* *}$ & 450 \\
\hline \multirow{3}{*}{$\mathrm{CuSO}_{4}+\mathrm{IAA}$} & 100 & 13.6 & 113.33 & 5.25 & 100 & $10.3^{* *}$ & 575 \\
\hline & 200 & 12.7 & 105.83 & 4.9 & 93.33 & $9^{* *}$ & 500 \\
\hline & 350 & 11.6 & 96.67 & 4.9 & 93.33 & $9.0^{* *}$ & 500 \\
\hline L. S. D. $0.05 \%$ & & 1.50 & & 0.54 & & 0.71 & \\
\hline \multirow[t]{2}{*}{ cv. Assiut 125} & 0 & 10.1 & 100 & 1.5 & 100 & 3.6 & 100 \\
\hline & 100 & $11.8^{*}$ & 116.83 & 1.5 & 100 & 3.6 & 100 \\
\hline \multirow[t]{3}{*}{$\mathrm{CuSO}_{4}$} & 200 & 10.5 & 103.96 & 1.5 & 100 & 6.3 & 175 \\
\hline & 350 & 10.5 & 103.96 & 1.5 & 100 & 3.6 & 100 \\
\hline & 0 & 10.2 & 100.99 & $3.25^{\star *}$ & 216.67 & $10.8^{\star *}$ & 300 \\
\hline \multirow{3}{*}{$\mathrm{CuSO}_{4}+\mathrm{IAA}$} & 100 & $12.0^{*}$ & 118.81 & $3.00^{* *}$ & 200 & $9.9^{* *}$ & 275 \\
\hline & 200 & $13.1^{\star *}$ & 129.70 & $3.00^{* *}$ & 200 & $8.55^{\star *}$ & 237.5 \\
\hline & 350 & $12.6^{* *}$ & 124.75 & $3.25^{* *}$ & 216.67 & $4.95^{\star}$ & 137.5 \\
\hline L. S. D. $0.05 \%$ & & 1.16 & & 0.18 & & 0.99 & \\
\hline
\end{tabular}

*Significant differences and ${ }^{* *}$ highly significant differences as compared to the absolute control.

Assiut 125 a highly significant increase in $\mathrm{K}$ contents was recorded when the $\mathrm{Cu}$-affected plants were sprayed by IAA (Table 3). The pods of cv. Assiut 125 seemed to be more potassium-accumulators than the pods of $\mathrm{cv}$. Assiut 84, whatever the used type of treatments. IAA treatments ameliorated the drastic effects of $\mathrm{Cu}$ on $\mathrm{Ca}^{+2}$ content in pods of cv. Assiut 84 (Table 3). This promotion was more pronounced at the highest dose of $\mathrm{Cu}^{2+}$. A marked and progressive increase in $\mathrm{Ca}^{2+}$ content in pods of $\mathrm{cv}$. Assiut 125 was obtained by IAA treatments. $\mathrm{Ca}^{2+}$ content was 2.5 -fold that of control as a result of $350 \mathrm{ppm} \mathrm{Cu}^{2+}$ plus IAA. In cv. Assiut 84 a huge accumulation of magnesium was recorded by IAA treatments (Table 3). The percent of this increase was 350\%, 475\%, 400\% and 325\% at the level of 0,100200 and $350 \mathrm{ppm} \mathrm{Cu}$, respectively. IAA resulted in a marked and progressive, but irregular, increase in magnesium content in pods of cv. Assiut 125 (Table 3 ). The percent increase in pods treated by $0 \mathrm{Cu}^{2+}$ plus IAA, 100 ppm $\mathrm{Cu}^{2+}$ plus IAA, $200 \mathrm{ppm} \mathrm{Cu}^{2+}$ plus IAA and $350 \mathrm{ppm} \mathrm{Cu}^{2+}$ plus IAA was $200 \%, 175 \%, 137 \%$ and only $37.5 \%$, respectively (Table 3 ). 


\subsection{The Concentration of Some Microelements and Interaction with IAA}

The most striking feature in this work is that while the pods of cv. Assiut 84 accumulated a huge amount of $\mathrm{Al}$ at the level of control, the concentration of 350 ppm $\mathrm{Cu}^{2+}$ slowed down this accumulation of $\mathrm{Al}$ to about $50 \%$, which may be one of the defense mechanisms of this cultivar against copper toxicity (Tables 4-6). This was recommended in plants treated by IAA when the concentration of Al was highly significantly retarded at the level of control as well as the level of 350 ppm $\mathrm{Cu}^{2+}$, it was reduced to about $70 \%$ in both (Figure 1 ). Thus, the mechanism of IAA in alleviating the toxic copper effect in the pods of this cultivar may be associated with the retardation of $\mathrm{Al}$ content (Table 4). In this context a surprising situation was recorded in cv. Assiut 125. The pods of this cultivar accumulated small amounts of this toxic element (Al) at the level of control. This small amount of $\mathrm{Al}$ was reduced more in pods treated by $350 \mathrm{ppm} \mathrm{Cu}^{2+}$ (Figure 2). This was associated with the converting situation of the two cultivars when transported into the fruiting stage. The amount of $\mathrm{Cd}$ seemed to be very small in the pods of the two tested broad bean cultivars grown under different treatments, which indicates that the used soil is very rare in Cd ion (Table 4). However, the highest amount of this heavy metal was found in cv. Assiut 84 only at the level of controls (control and control plus IAA). In general, pods treated by IAA, either with or without copper, accumulated higher amounts of Co than those untreated by IAA (Table 4). This again confirmed the alleviating role of IAA (cobalt is considered an essential microelement when present at suitable concentrations). There is a considerable variation in the $\mathrm{Cu}$ contents in pods among the two tested cultivars. In cv. Assiut 84, the pods treated by $350 \mathrm{ppm} \mathrm{Cu}$ accumulated a high amount of $\mathrm{Cu}$ in relation to its control (1.6 to $2.8 \mathrm{mg} / 100$ gm dry matter) (Table 4; Figure 1). On the other hand, the pods of cv. Assiut 125 succeeded to keep the $\mathrm{Cu}$ content around its control value, which again might confirm the opposing situation of the two cultivars from the vegetative into the fruiting stages of growth (Table 4; Figure 1). Another important situation was also located in the variations in the accumulation of $\mathrm{Fe}$ in the pods of the two broad bean cultivars grown under different copper treatments (Table 4 and Figure 1). In cv. Assiut 84 a huge accumulation of Fe was recorded in pods treated by $350 \mathrm{ppm} \mathrm{Cu}^{2+}$, in relation to the control $(16.04$ to $44.00 \mathrm{mg} / 100 \mathrm{gm}$ dry matter). Interestingly, the opposite occurred in cv. Assiut 125 where the accumulation of Fe was retarded by $350 \mathrm{ppm} \mathrm{Cu}^{2+}$, treatment (Table 4; Figure 1). Phytohormonal treatments seemed to play different roles in the accumulation of Fe (Table 4; Figure 1). While IAA induced insignificant changes in the Fe content of the pods of $\mathrm{cv}$. Assiut 84, it, on the other hand, induced a marked increase in this element in the pods of cv. Assiut 125, particularly in pods treated by IAA without copper treatment (Table 4; Figure 1). Zn content in pods of $\mathrm{cv}$. Assiut 84 reduced to about $50 \%$ as a result of $350 \mathrm{ppm} \mathrm{Cu}^{2+}$ treatment (Table 4; Figure 1). In cv. Assiut 125, as in the case of Fe, there is no obvious difference in 
Table 4. Effect of $\mathrm{CuSO}_{4}$ and $\mathrm{CuSO}_{4}$ plus IAA on the contents of some microelements (mg.100 $\mathrm{g}^{-1} \cdot \mathrm{d} \cdot \mathrm{m}$.) in the broad bean cultivars Assiut 84 a and Assiut 125 (b).

(a)

\begin{tabular}{|c|c|c|c|c|}
\hline Element & Cont. & $350 \mathrm{ppm} \mathrm{Cu}{ }^{2+}$ & Cont. + IAA & $\begin{array}{c}350 \mathrm{ppm} \mathrm{Cu}^{2+}+ \\
\text { IAA }\end{array}$ \\
\hline Aluminum & 28.40 & $15.20^{\star *}$ & 9.70 & 10.90 \\
\hline Iron & 16.04 & $44.30^{\star \star}$ & 15.80 & $17.00^{*}$ \\
\hline Zinc & 6.93 & $3.90^{* *}$ & 4.40 & 5.50 \\
\hline Boron & 2.80 & 2.90 & 2.60 & 2.50 \\
\hline Manganese & 2.60 & 2.60 & 2.90 & 2.90 \\
\hline Cadmium & 0.02 & 0.01 & 0.02 & 0.01 \\
\hline Cobalt & 0.02 & 0.01 & 0.05 & 0.03 \\
\hline Lead & 0.40 & 0.20 & 0.20 & 0.20 \\
\hline Chromium & 0.21 & 0.41 & 0.20 & 0.20 \\
\hline Copper & 1.60 & 2.80 & 2.50 & 2.90 \\
\hline
\end{tabular}

(b)

\begin{tabular}{ccccc}
\hline Element & Cont. & $350 \mathrm{ppm} \mathrm{Cu}$ & Cont. + IAA & $350 \mathrm{ppm} \mathrm{Cu}+$ IAA \\
\hline Aluminum & 8.70 & 7.40 & 12.40 & 11.30 \\
Iron & 13.60 & $10.40^{* *}$ & 24.20 & $14.20^{* *}$ \\
Zinc & 2.70 & 2.50 & 4.10 & 3.60 \\
Boron & 2.30 & 1.90 & 2.70 & 2.50 \\
Manganese & 1.70 & 2.02 & 2.30 & 2.50 \\
Cadmium & 0.01 & 0.01 & 0.01 & 0.01 \\
Cobalt & 0.02 & 0.02 & 0.02 & 0.02 \\
Lead & 0.2 & 0.01 & 0.2 & 0.1 \\
Chromium & 0.2 & 0.20 & 0.22 & 0.23 \\
Copper & 1.7 & 1.9 & 2.20 & 2.30 \\
\hline
\end{tabular}

*Significant differences and ${ }^{*}$ highly significant differences as compared to the absolute control.

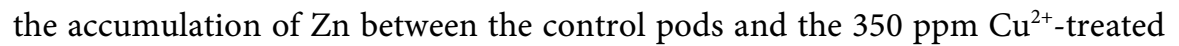
pods (Table 4; Figure 1). Hormonal treatments stimulated the accumulation of this element in the pods of the two tested cultivars treated with or without copper (Table 4; Figure 1). However, as in the case of Al, the highest amount of $\mathrm{Zn}$ was obtained in the control pods of cv. Assiut 84 (Table 4; Figure 1). A small amount of $\mathrm{Pb}$ was recorded in pods of the two tested cultivars under the various treatments (Table 4; Figure 1). The dominant concentration of $\mathrm{Pb}$ was 0.2 $\mathrm{mg} / \mathrm{gm}$ dry matter, except for the pods of cv. Assiut 125 treated by $350 \mathrm{ppm} \mathrm{Cu}^{2+}$ or $350 \mathrm{ppm} \mathrm{Cu}{ }^{2+}$ plus IAA $(0.1 \mathrm{mg} / 100 \mathrm{gm}$ dry matter) and in pods of cv. Assiut 84 treated by $\mathrm{H}_{2} \mathrm{O}(0.4 \mathrm{mg} / 100$ gm dry matter) (Table 4; Figure 1). The amount of $\mathrm{Mn}$ in the differently treated pods was more or less similar in the two cultivars (Table 4; Figure 1). It fluctuated between 2.3 and $2.9 \mathrm{mg} / 100 \mathrm{gm}$ dry matter, 
Table 5. Effect of $\mathrm{CuSO}_{4}$ and $\mathrm{CuSO}_{4}$ plus IAA on the individual amino acids in the broad bean cultivar Assiut 84 (mg/100 gm protein).

\begin{tabular}{ccccccccc}
\hline Amino acids & Cont. & $\%$ & $\begin{array}{c}350 \mathrm{ppm} \\
\mathrm{Cu}^{2+}\end{array}$ & $\%$ & $\begin{array}{c}\text { Cont. }+ \\
\text { IAA }\end{array}$ & $\begin{array}{c}350 \mathrm{ppm} \\
\mathrm{Cu}^{2+}+\text { IAA }\end{array}$ & $\%$ \\
\hline Aspartic acid & 6.60 & 100 & 7.19 & 108.94 & 7.54 & 114.24 & 8.76 & 132.73 \\
Threonine & 2.13 & 100 & 2.18 & 102.35 & 2.30 & 107.98 & 2.11 & 99.06 \\
Serine & 3.62 & 100 & 3.97 & 109.67 & 4.03 & 111.33 & 3.68 & 101.66 \\
Glutamine & 7.29 & 100 & 8.72 & 119.62 & 9.00 & 123.46 & 7.94 & 108.92 \\
Proline & 0.44 & 100 & 0.46 & 104.55 & 0.44 & 100 & 0.43 & 97.73 \\
Glycine & 5.21 & 100 & 5.85 & 112.28 & 5.80 & 111.32 & 5.70 & 109.40 \\
Alanine & 3.96 & 100 & 4.21 & 106.31 & 4.37 & 110.35 & 4.97 & 125.51 \\
Valine & 2.65 & 100 & 2.76 & 104.15 & 2.86 & 107.92 & 2.60 & 98.11 \\
Methionine & & & & & & & & \\
Isoleucine & 2.11 & 100 & 2.23 & 105.69 & 2.27 & 107.58 & 1.13 & 53.55 \\
Leucine & 4.61 & 100 & 4.95 & 107.38 & 5.13 & 111.28 & 5.88 & 127.55 \\
Tyrosine & 1.55 & 100 & 1.56 & 100.65 & 1.69 & 109.03 & 1.22 & 78.71 \\
Tyrosine & & & & & & & 1.00 & \\
Phenylalanine & 1.63 & 100 & 1.65 & 101.23 & 1.77 & 108.59 & 1.60 & 98.16 \\
Histdine & 1.14 & 100 & 1.33 & 116.67 & 1.74 & 152.63 & 1.53 & 134.21 \\
Lysine & 3.07 & 100 & 3.59 & 116.94 & 3.80 & 123.78 & 3.41 & 111.07 \\
NH ${ }_{3}$ & 6.34 & 100 & 7.54 & 118.93 & 7.98 & 125.87 & 10.34 & 163.09 \\
Argenine & 2.71 & 100 & 3.36 & 123.98 & 5.29 & 195.20 & 4.11 & 151.66 \\
Total & 55.07 & 100 & 61.55 & 111.77 & 65.99 & 119.83 & 66.40 & 120.57 \\
\hline & & & & & & & & \\
\hline
\end{tabular}

except for pods of cv. Assiut 125 under $\mathrm{H}_{2} \mathrm{O}$ irrigation $(1.7 \mathrm{mg} / 100$ gm dry matter). Also there is a general promotion in the contents of this element as a result of IAA treatment, whatever the cultivar or the treatment (Table 4; Figure 1). The amount of B was more or less similar under the different treatments in the pods of the two tested cultivars ( 2.5 to $2.9 \mathrm{mg} / 100 \mathrm{gm}$ dry matter), except for the pods of cv. Assiut 125 treated by $350 \mathrm{ppm} \mathrm{Cu} \mathrm{(1.9} \mathrm{mg/100} \mathrm{gm} \mathrm{dry} \mathrm{matter)}$ (Table 4; Figure 1). Also there is some promotion in the accumulation of this element in the pods of cv. Assiut 125 either treated or untreated by copper in relation to the control values when sprayed by IAA (Table 4; Figure 1).

\subsection{Contents of Total and Individual Amino Acids}

Amino acids contents and their individuals varied considerably among the two tested cultivars. Copper treatment enhanced the accumulation of amino acids in the pods of cv. Assiut 84 in relation to its control. Additional enhancement in these contents was observed when the copper-treated plants were sprayed by IAA. On the other hand, in cv. Assiut 125 the total amino acids contents dropped highly significantly by copper treatment. However, they were considerably 
Table 6. Effect of $\mathrm{CuSO}_{4}$ and $\mathrm{CuSO}_{4}$ plus IAA on the individual amino acids in the broad bean cultivar Assiut 125 (gm/100 gm protein).

\begin{tabular}{|c|c|c|c|c|c|c|c|c|}
\hline Amino acids & Cont. & $\%$ & $\begin{array}{c}350 \mathrm{ppm} \\
\mathrm{Cu}\end{array}$ & $\%$ & $\begin{array}{l}\text { Cont. + } \\
\text { IAA }\end{array}$ & $\%$ & $\begin{array}{c}350 \mathrm{ppm} \\
\mathrm{Cu}+\mathrm{IAA}\end{array}$ & $\%$ \\
\hline Aspartic acid & 7.53 & 100 & 4.42 & 58.70 & 5.50 & 73.04 & 10.17 & 135.06 \\
\hline Threonine & 2.58 & 100 & 1.34 & 51.94 & 1.86 & 72.09 & 3.54 & 137.21 \\
\hline Serine & 4.18 & 100 & 2.30 & 55.02 & 3.31 & 79.19 & 5.92 & 141.63 \\
\hline Glutamine & 9.61 & 100 & 5.14 & 53.49 & 7.00 & 72.84 & 13.54 & 140.89 \\
\hline Proline & 0.55 & 100 & 0.21 & 38.18 & 0.41 & 74.55 & 0.76 & 138.18 \\
\hline Glycine & 6.13 & 100 & 3.47 & 56.61 & 4.75 & 77.49 & 8.49 & 138.50 \\
\hline Alanine & 4.61 & 100 & 2.56 & 55.53 & 3.74 & 81.13 & 6.15 & 133.41 \\
\hline Valine & 2.96 & 100 & 1.59 & 53.72 & 2.31 & 78.04 & 3.47 & 117.23 \\
\hline Methionine & & & & & & & 3.12 & \\
\hline Isoleucine & 2.34 & 100 & 1.29 & 55.13 & 1.90 & 81.20 & 7.22 & 308.55 \\
\hline Leucine & 5.32 & 100 & 2.92 & 54.89 & 4.01 & 75.38 & 0.31 & 5.83 \\
\hline Tyrosine & 1.36 & 100 & 0.88 & 64.71 & 0.41 & 30.15 & 1.48 & 108.82 \\
\hline Phenylalanine & 1.77 & 100 & 0.96 & 54.24 & 0.75 & 42.37 & 2.17 & 122.60 \\
\hline Phenylalanine & & & & & 1.25 & & & \\
\hline Histdine & 1.87 & 100 & 1.01 & 54.01 & 1.31 & 70.05 & 2.37 & 126.74 \\
\hline Lysine & 4.31 & 100 & 1.73 & 40.14 & 2.73 & 63.34 & 4.53 & 105.10 \\
\hline $\mathrm{NH}_{3}$ & 7.26 & 100 & 5.24 & 72.18 & 4.73 & 65.16 & 10.76 & 148.21 \\
\hline Argenine & 4.34 & 100 & 2.67 & 61.52 & 3.14 & 72.35 & 6.63 & 152.77 \\
\hline Total & 66.72 & 100 & 37.73 & 56.55 & 49.12 & 73.62 & 90.61 & 135.81 \\
\hline
\end{tabular}

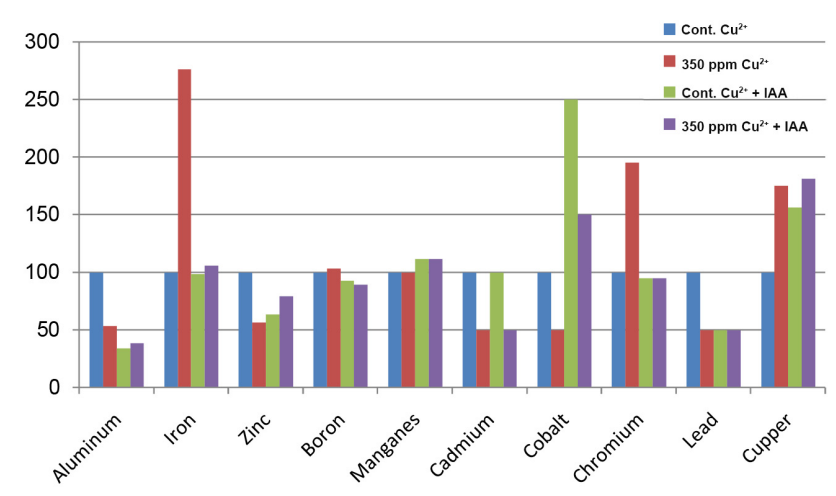

(a)

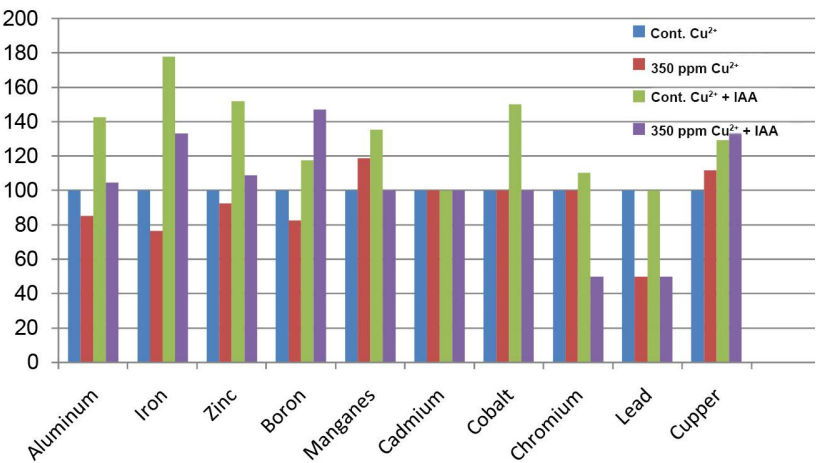

(b)

Figure 1. Effect of $\mathrm{CuSO}_{4}$ and $\mathrm{CuSO}_{4}$ plus IAA on percent contents of some microelements (mg.100.g $\mathrm{g}^{-1} \mathrm{~d} \cdot \mathrm{m}$.) in the broad bean cultivars Assiut 84 (a) and Assiut 125 (b).

enhanced by $\mathrm{Cu}^{2+}$ plus IAA treatment. In cv. Assiut 84 all of the individual amino acids increased by $\mathrm{Cu}^{2+}, \mathrm{H}_{2} \mathrm{O}$ plus IAA or $\mathrm{Cu}^{2+}$ plus IAA treatments, except for isoleucine and tyrosine which dropped as a result of $350 \mathrm{ppm} \mathrm{Cu}^{2+}$ plus IAA treatment. On the other hand, the contents of these amino acids dropped highly 


\section{In the pods of cv. Assiut 84} treated by $\mathrm{H}_{2} \mathrm{O}$

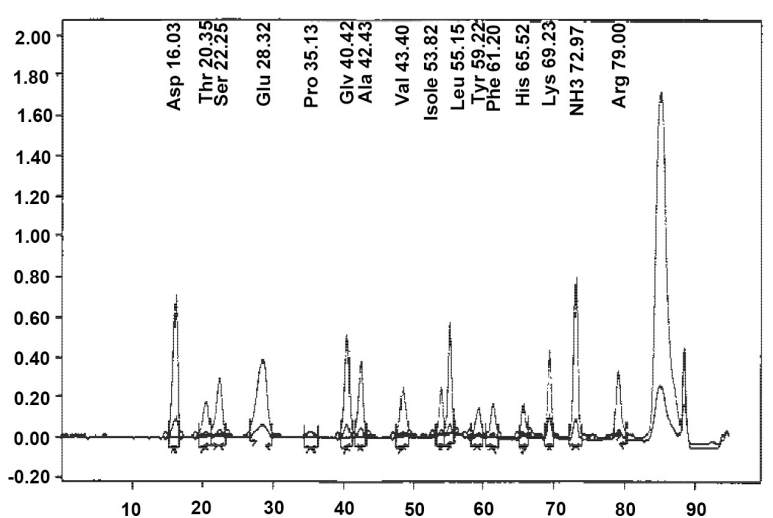

In the pods of $\mathrm{cv}$. Assiut 125 treated by $\mathrm{H}_{2} \mathrm{O}$

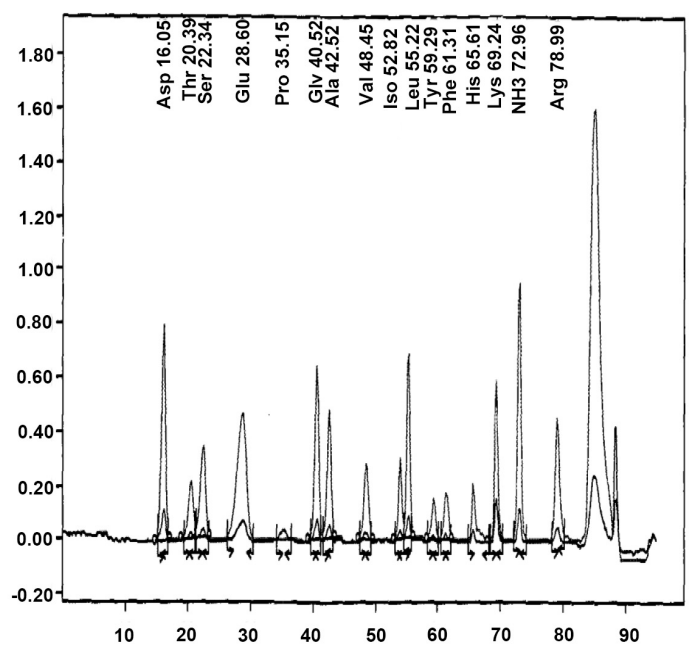

In the pods of cv. Assiut 84 treated by $350 \mathrm{ppm} \mathrm{\textrm {Cu } ^ { 2 + }}$

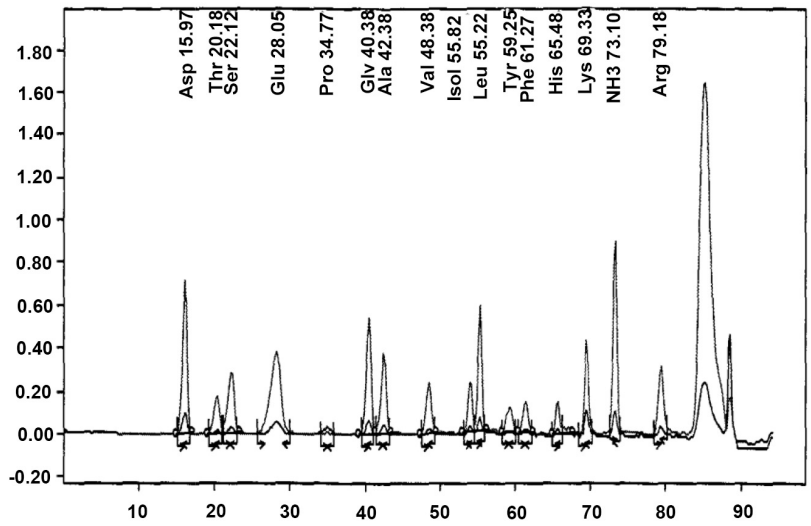

In the pods of cv. Assiut 125 treated by $350 \mathrm{ppm} \mathrm{Cu^{2+ }}$

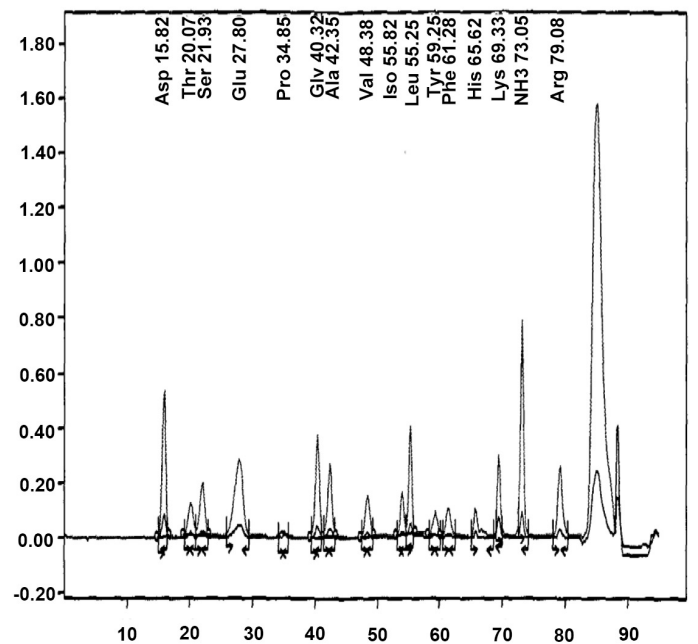

Figure 2. Effect of $\mathrm{CuSO}_{4}$ and $\mathrm{CuSO}_{4}$ plus IAA on the individual amino acids (gm/100 gm protein) in the pods of broad bean cultivars Asiut 84 and Assiut 125.

significantly in the pods of the copper-treated cv. Assiut 125. IAA treatment of the copper-affected pods of this cultivar succeeded in increasing the accumulation of all of these amino acids (except for leucine) over the values of the control plants. The uptake of nutrients was greatly impacted in response to copper stress.

\section{Discussion}

It is worthy to mention that the two broad bean cultivars displayed a surprising situation during the fruiting stage of growth to copper treatments. The absolute amount of pods yield was higher in cv. Assiut 125 than in cv. Assiut 84, this 
might be interpreted by the effect of the environmental stresses which is different with the different species, cultivars intensity, rate and duration of exposure and the stage of crop growth [27] [28] [29]. Hamdia et al. (2018) [30] stated that there are major differences in the response of the two broad bean cultivars Assiut 84 and Assiut 125 to copper treatments during the vegetative stage from one hand and at the crop yield from the other. We preferred to use the growth criteria of roots, stems and leaves during the vegetative stage as a suitable selection criterion for the copper responses of the two cultivars. The alterations in anatomical parameters and grain yield of different crop plants as a result of heavy metal stress have been previously reported [31] [32] [33] [34]. The data in fresh and dry matter yields of pods revealed interesting results, although the cv. Assiut 84 was less affected by the highest dose of copper, the cv. Assiut 125 was greatly affected by this dose (around 37\% reduction in fresh and dry matter of pods compared to insignificant changes in these values in cv. Assiut 84). However, another surprising situation was recorded when the absolute values in fresh and dry matter of cv. Assiut 125 were much higher than cv. Assiut 84. The fresh matter in cv. Assiut 84 and cv. Assiut 125 was $7.24 \mathrm{gm}$ and $10.16 \mathrm{gm}$ at the level of control and $6.69 \mathrm{gm}$ and $7.59 \mathrm{gm}$ at the level of $350 \mathrm{ppm} \mathrm{Cu}^{2+}$, respectively. Their dry matter was 1.99 and $3.52 \mathrm{gm}$ at the level of control and 1.77 and 2.13 $\mathrm{gm}$ at the level of $350 \mathrm{ppm} \mathrm{Cu}^{2+}$ in cv. Assiut 84 and cv. Assiut 125, respectively. This contradiction was also extended when these copper-affected cultivars were sprayed by IAA, the $\mathrm{cv}$. Assiut 84 responded slightly to IAA treatment. On the other hand, a considerable increase in the dry matter yield was recorded in the pods of cv. Assiut 125 at any used level of copper when compared to the non-sprayed plants treated by the same copper concentration. At the level of 350 ppm $\mathrm{Cu}^{2+}$, the pod yield was 2 -fold that of plants treated only by $350 \mathrm{ppm} \mathrm{Cu}^{2+}$, without IAA spraying. Thus, even IAA behaved differently in its effect on the crop yield of the two tested broad bean cultivars. Thus, the different effects of IAA (the complexity and diversity in the behavior of IAA) were not a concentration effect. These different effects might be due to the synergistic effect between IAA and the different growth hormones during the different growth stages, particularly flowering which are accompanied by the appearance of florigen and phytochromes (the flowering and fruiting hormones) [35] [36] [37]. The data of carbohydrates contents in pods reveal that although the carbohydrates content increased considerably by copper in the cv. Assiut 84, especially at the level of $200 \mathrm{ppm} \mathrm{Cu}^{2+}$ addition, another side there is a slightly increase in cv. Assiut 125 up to $200 \mathrm{ppm}$ only then, a reduction was recorded at $350 \mathrm{ppm} \mathrm{Cu}^{2+}$ treatment was recorded. Another situation was recorded a reduction in proteins values, was exhibited in cv. Assiut 84 and cv. Assiut 125. Thus, is there a correlation between increase in carbohydrate and a reduction protein metabolism in the pods of cv. Assiut 84 and cv. Assiut 125? The answer seemed to be complicated as these variable responses may be attributed to differences in genes expression and carbohydrates and proteins functions in different plant tissues. It has been 
shown that heavy metals also reduce biomass accumulation [5] [38] [39] [40] as a result of adverse effects upon key metabolic processes such as photosynthesis [41] (Rodriguez et al. 2012), mineral nutrition [42] and interactions with water [30] [33] [43]. The phytohormones, especially GAs, alleviate heavy metal stress before influencing other important developmental processes, such as flowering initiation, seed germination, and increasing plant height in crop plants [44] [45]. Similarly, in auxin groups, indole-3-acetic acid (IAA) is responsible for cell division, elongation, differentiation, root initiation, regulation of gene expression, and ROS homeostasis under abiotic stress conditions to enhance the growth and development process of the plant [46]. It is presumed that these findings might contribute to better understanding the response mechanisms of the two broad bean cultivars to copper stress and to further insights into copper-soil interaction in natural environments. There is a big variation in the accumulation of microelements and heavy metals in pods among the two broad bean genotypes. First of all, the water-treated pods of cv. Assiut 84 accumulated huge amount of aluminum. Interestingly, this amount of $\mathrm{Al}$ reduced by about $50 \%$ in pods of $\mathrm{cv}$. Assiut 84 when treated by $350 \mathrm{ppm} \mathrm{Cu}^{2+}$ and decreased by more than $66 \%$ and $67 \%$ as a result of control plus IAA and $350 \mathrm{ppm} \mathrm{Cu}^{2+}$ plus IAA treatments respectively. The following situation was recorded in cv. Assiut 125, a) there are no significant changes of $\mathrm{Al}$ content in $\mathrm{cv}$. Assiut 125 copper-treated pods. b) these values were considerably less than those of cv. Assiut 84. c) IAA enhanced the accumulation of this element in pods of cv. Assiut 125. A contrasting effect of IAA was exhibited IAA considerably reduced the accumulation of $\mathrm{Al}$ in cv. Assiut 84, it stimulated the accumulation of this element in the pods of cv. Assiut 125. These problematical behaviors (the correlation between $\mathrm{Cu}$ and $\mathrm{Al}$ ) evoked us to point out that: Firstly there are two contrasting situations in the effect of $\mathrm{Cu}^{2+}$ on the accumulation of $\mathrm{Al}$. In cv. Assiut 84 the amount of $\mathrm{Al}$ was reduced to about $50 \%$ by copper treatment, which means that the presence of copper in soil prevented the uptake of aluminum. On the other hand, in cv. Assiut 125 the concentration of $\mathrm{Al}$ in copper-treated pods seemed to be more or less similar to those of control. Accordingly, the differences in the uptake of Al could be attributed to cultivar variations rather than the effect of copper. Secondly this was recommended in hormonal-treated plants, that while IAA treatment dropped $\mathrm{Al}$ content in cv. Assiut 84, it stimulated the Al content in cv. Assiut 125, which again confirmed the complicated correlations of these genotypes and the role played by copper as well as IAA and the concentration effect of this dilemma might be ruled out. Al interference with the uptake, transport and utilization efficiency of most of the mineral elements have been well documented [47]. Tani and Barrington (2005) [48] showed that plant $\mathrm{Cu}$ and $\mathrm{Zn}$ uptake increased with two transpiration rates, with higher levels of $\mathrm{Cu}, \mathrm{Zn}$ uptake by buckwheat was significantly reduced, while $\mathrm{Zn}$ had a slight but non-significant impact on $\mathrm{Cu}$ uptake. Previously and in a study exposing wheat plants to the same conditions, $\mathrm{Cu}$ significantly increased $\mathrm{Zn}$ uptake, while $\mathrm{Zn}$ had a slight but insignificant 
negative effect on $\mathrm{Cu}$ uptake. The buckwheat roots contained the greatest levels of $\mathrm{Cu}$ and $\mathrm{Zn}$, indicating their role in moderating heavy metal uptake. The accumulation of iron was also interesting, in cv. Assiut 84, Fe considerably accumulated in copper-treated pods (it reached $276.14 \%$ of control). The opposite cut held in cv. Assiut 125 where iron was reduced by $23.6 \%$ in copper-treated pods in comparison with those of control. Hormonal treatments behaved differently among the two cultivars treated or not treated by copper. In cv. Assiut 84, IAA induced insignificant changes in iron content at the level of controls, but it considerably dropped the amount of iron in copper-treated plants, it retained the amount of $\mathrm{Fe}$ in copper-treated pods around their control. In cv. Assiut 125, while IAA nearly doubled the Fe content at the level of controls, it also, as in the case of cv. Assiut 84, retained the amount of Fe in copper-treated pods around their control. Why copper induced this considerable accumulation of iron only in cv. Assiut 84, is still a complicated question. Again, like aluminum, iron is copper independent, it is cultivar-dependent. Pätsikkä et al. (2002) [49] observed that excess $\mathrm{Cu}$ in hydroponic medium induces a Fe-deficiency in bean plants. Chen et al. (2004) [50] observed that Fe-deficiency induces $\mathrm{Cu}$ accumulation in Commelina communis L. plants. Yruela (2005) [51] reported that $\mathrm{Cu}$ and $\mathrm{Fe}$ compete in ion-uptake. Furthermore, Rombolà et al. (2005) [52] found that Fe deficiency increases the $\mathrm{Cu}$ content and decreases the $\mathrm{Zn}$ content in leaf blades of sugar beet grown hydroponically. $\mathrm{Cu}$ and $\mathrm{Fe}$ antagonism often occurs in plants grown under $\mathrm{Cu}$ toxicity [53]. These reports are not in agreement with our results. However, the opposite scenario has been also observed in oregano [54], rice seedlings [55] and wheat (Triticum aestivum L. cv. Vergina) [56] plants exposed to $\mathrm{Cu}$ toxicity in soil. An increasing concentration of soil $\mathrm{Cu}^{2+}$ resulted in a parallel increase in leaf $\mathrm{Cu}$ content with no reduction in the leaf $\mathrm{Fe}$ and Mg. Lara and Luca (2004) [57] reported that as the medium Cu concentration increased from 0.1 to $50 \mu \mathrm{M}$, iron uptake was strongly stimulated as indicated by tissue $\mathrm{Fe}$ concentration. Increasing the media $\mathrm{CuSO}_{4}$ concentration to $100 \mu \mathrm{M}$ had no effect stimulating Fe uptake. These apparently contradictory results may be explained by different tolerance strategies adopted by different plants [58] [59] [60] [61]. Bernal et al. (2007) [62] demonstrated that $\mathrm{Cu}$ interacts differently with $\mathrm{Fe}$ and $\mathrm{Zn}$ depending on the pathway through excess $\mathrm{Cu}$ is supplied. In the present work, cultivars variations as well as copper effect were also recorded in the absorption of zinc. While the $\mathrm{Zn}$ content in the pods of $\mathrm{cv}$. Assiut 84 was more than double of that in cv. Assiut 125 at natural conditions, under copper treatments, while $\mathrm{Cu}$ caused a drop in the $\mathrm{Zn}$ content to about $50 \%$ in $\mathrm{cv}$. Assiut 84, it, on the other hand, induced insignificant changes in this cation in cv. Assiut 125. In agreement with our data, Panou-Filotheou and Bosabalidis (2004) [63] reported that soil $\mathrm{Cu}^{2+}$ affected negatively the accumulation of $\mathrm{Zn}$ in roots of oregano. Additionally, an antagonist interaction between $\mathrm{Cu}$ and $\mathrm{Zn}$ was observed in Chlamydomonas reinhardtii [58]. Zinc plays an important role as an essential trace element in all living systems from bacteria to hu- 
mans [64]. Interestingly, the opposite event was recorded in boron contents. While B remained around the control values in the copper-treated pods of $\mathrm{cv}$. Assiut 84, it decreased significantly in pods of cv. Assiut 125 as a result of copper treatment. Results from Laboratory and Screen house experiments have been made by Azeez et al. (2015) [65] showed significant decrease in soil available P, $\mathrm{Zn}$ and $\mathrm{Fe}$ as rates of $\mathrm{Cu}$ increase over control experiment. The effect was more pronounced at application rate above $20 \mathrm{mg} \cdot \mathrm{kg}^{-1} \mathrm{Cu}$. Gradual decrease in maize plant height, stem girth, leaf areas index, $\mathrm{P}, \mathrm{Zn}$ and Fe uptake were observed as rate of $\mathrm{Cu}$ application increased. Hormonal treatment in most cases stimulated the accumulation of $\mathrm{Zn}$ in the two cultivars. Thus, the effect of IAA on $\mathrm{Zn}$ content was more or less similar in the two cultivars. This was opposite to its effect on $\mathrm{Al}$ and $\mathrm{Fe}$, IAA induced almost insignificant changes in $\mathrm{B}$ contents. The amount of B was nearly the same in the two cultivars, whatever the treatments used, except for cv. Assiut 125 where there is some reduction in this element as a result of copper treatment. There are no significant changes in manganese content in pods of the two broad bean cultivars, whatever the treatments used. Yang and You (2009) [66] reported that $\mathrm{Al}$ can also reduce $\mathrm{Mn}$ toxicity and $\mathrm{Mn}$ accumulation in the plant. Thus, it is speculated that $\mathrm{Al}$ exerts an antagonistic effect on Mn uptake, and thus leads to alleviated Mn toxicity. Aluminum interference with $\mathrm{P}$ uptake might result in $\mathrm{P}$ deficiency in plants grown on acid soils or in nutrient solutions [67]. The pods of the two cultivars received very minute amounts of cadmium and cobalt, whatever the treatments used. Consequently, there are no differences in the accumulation of the two elements, which indicated that the used natural soil was very poor in $\mathrm{Cd}$ and $\mathrm{Co}$. Lead $(\mathrm{Pb})$ belongs among nonessential metals for plants and has no known biological function, and probably is one of the most frequently encountered heavy metals in polluted environment [68] [69]. Lead content is reduced by $50 \%$ as a result of copper treatment in the two tested cultivars. IAA mostly induced insignificant changes in $\mathrm{Pb}$ content except for cv. Assiut 84 plants irrigated by $\mathrm{H}_{2} \mathrm{O}$, where this element was reduced by $50 \%$ in relation to the control. The data of chromium indicated that while copper increased $\mathrm{Cr}$ content by about $100 \%$ in cv. Assiut 84 , it, on the other hand, induced insignificant changes in pods of cv. Assiut 125 in relation to the control values. The results of copper content in pods of cv. Assiut 84 and cv. Assiut 125 reveal that while exogenous application of $\mathrm{Cu}^{2+}$ nearly doubled the $\mathrm{Cu}^{2+}$ content in pods of $\mathrm{cv}$. Assiut 84 , it induced a slight increase in $\mathrm{Cu}^{2+}$ content in pods of cv. Assiut 125. The percent increase in $\mathrm{Cu}$ contents in pods of cv. Assiut 84 and cv. Assiut 125 were $75 \%$ and only $11 \%$ respectively. Unexpectedly, the amount of copper increased highly significantly when the copper-treated plants were sprayed by IAA. This stimulatory effect in the uptake of $\mathrm{Cu}$ by IAA was more pronounced in cv. Assiut 84 than in cv. Assiut 125. It is worthy to mention that the amount of $\mathrm{Cu}$ in pods of $\mathrm{cv}$. Assiut 84 subjected to $350 \mathrm{ppm}$ $\mathrm{Cu}^{2+}$ was similar to that in pods treated by $350 \mathrm{ppm} \mathrm{Cu}^{2+}$ plus IAA, 2.8 and 2.9 $\mathrm{mg} / 100 \mathrm{gm}$ dry matter, respectively. The corresponding values in cv. Assiut 125 
were 1.9 and $2.3 \mathrm{mg} / 100 \mathrm{gm}$ dry matter in pods of $350 \mathrm{ppm} \mathrm{Cu}^{2+}$ and $350 \mathrm{ppm}$ $\mathrm{Cu}^{2+}$ plus IAA, respectively, which also recommended the different responses to IAA according to the cultivars variations and the different treatments. Interactions of $\mathrm{Zn}, \mathrm{Mn}$, and $\mathrm{Cu}$ with macro and micronutrients are either synergistic, antagonistic or have no effects, depending on crop species and nutrients under investigation [70]. No consistent correlation was found between the Cu levels in the nutrient solution and either Fe or Mn levels in roots, stems, or leaves [59]. However, copper had significant synergistic effect on the uptake of $\mathrm{P}, \mathrm{K}$, and $\mathrm{Mn}$ in the upland rice plants. However, concentration of $\mathrm{Ca}, \mathrm{Mg}$ and $\mathrm{Fe}$ were significantly decreased in these plants with the application of copper. Copper did not influence significantly uptake of $\mathrm{Zn}$ in rice plants. In bean plants, $\mathrm{Cu}$ application significantly increased uptake of $\mathrm{Zn}$ and had no significant effect on uptake of $\mathrm{P}$, $\mathrm{K}, \mathrm{Ca}, \mathrm{Mg}, \mathrm{Mn}$ andiron [71]. Ahmed et al. (2012) [72] reveal that treatments with different levels of $\mathrm{Zn}(0,37.5$ and $75 \mathrm{ppm})$, tryptophan (25, 50 and 100 ppm) and IAA (100, 200 and $300 \mathrm{ppm})$ foliar applications improved growth characters (shoot length, shoot thickness, leaves number, and leaves area), yield and fruit quality through their favorable effects on leaves chemical composition (plant pigments, total sugars, total soluble phenols, total free amino acids, tryptophan and endogenous plant hormones balance of leaves) as well as nutritional status (N, P, K, Mg, Zn, Cu, Fe and Mn concentrations) of leaves of Valencia orange trees. Chuan et al. (2016) [73] study the effect of various growth parameters on heavy metal uptake of vetiver grass and PGP traits enhanced the heavy metal remediation in the sterile Laboratory scale. Fassler et al. (2010) [74] he use of plants for phytoextraction of heavy metals from contaminated soil is limited by the ability plants to grow on these soils and take up the target metals, as well as by the availability of the metals for plant uptake in the soil solution. The hypotheses of this study were that the growth-promoting phytohormoneauxin (indole-3-acetic acid, IAA) can alleviate toxic effects of metals on plants and increase metal phytoextraction in combination with the biodegradable chelating agent ethylene diamine disuccinic acid (EDDS). Neto et al. (2017) [33] stated that heavy metals are natural non-biodegradable constituents of the Earth's crust that accumulate and persist indefinitely in the ecosystem as a result of human activities. Since the industrial revolution, the concentration of cadmium, arsenic, lead, mercury and zinc, amongst others, have increasingly contaminated soil and water resources, leading to significant yield losses in plants. These issues have become an important concern of scientific interest. Understanding the molecular and physiological responses of plants to heavy metal stress is critical in order to maximize their productivity. Recent research has extended our view of how plant hormones can regulate and integrate growth responses to various environmental cues in order to sustain life. In the present review we discuss current knowledge about the role of the plant growth hormones abscisic acid, auxin, brassinosteroid and ethylene in signaling pathways, defense mechanisms and alleviation of heavy metal toxicity. The data of individual ami- 
no acids reveal that there is a big difference in the concentration of the total amino acids among the two broad bean cultivars as a result of the different treatments $\left(\mathrm{Cu}^{2+}\right.$ or $\mathrm{Cu}^{2+}$ plus IAA). In cv. Assiut 84 , there is some activation in the total amino acids content in the pods as a result of $\mathrm{Cu}^{2+}$ or $\mathrm{Cu}^{2+}$ plus IAA treatments in relation to the absolute control value. This enhancement was more pronounced under the interactive effect of $\mathrm{Cu}^{2+}$ and IAA. This increase in the amino acids concentrations means that this cultivar used these amino acids to phytochelatin the excess copper and consequently to reduce its toxicity. This may be one of the defense strategies adopted by this cultivar and led to the maintenance of the values of the crop yield mostly around the control values, even at the severe dose of copper (the dry matter of the $350 \mathrm{ppm} \mathrm{Cu}^{2+}$-treated pods is about $90 \%$ that of control pods). These increased amino acids could be used as free radical scavenger agents. The scavenging of the reactive oxygen species in heavy metal-treated plants is known to be a very important defense mechanism against the heavy metals toxicity. Interestingly, another situation was recorded in cv. Assiut 125, where the total amino acids in the pods dropped markedly by $\mathrm{Cu}^{2+}$ treatment. They were reduced by about $43 \%$ as a result of copper treatment. This situation confirms the role of amino acids as a defense mechanism against copper toxicity when we take into consideration the highly significant drop in the crop yield of this cultivar as a result of $350 \mathrm{ppm} \mathrm{Cu}^{2+}$ treatment (the pods dry matter was about $60 \%$ that of control as a result of 350 ppm $\mathrm{Cu}^{2+}$ treatment) (Sharma and Dietz (2006) [75]. Generally, heavy metal stress leads to a decrease in endogenous levels of auxins. For example, arsenic (As) is able to alter levels of three auxins (IAA, NAA, and indole-3-butyric acid, IBA) in Brassica juncea [76]. In another case, short-term cadmium treatment disturbed IAA homeostasis in barley root tips [77]. Previous work also indicates that Cadmium (Cd) suppresses primary root elongation in Arabidopsis [78]. Despite the detrimental effect of heavy metal in auxin metabolism, it has been reported that exogenous application of these phytohormones can rescue the endogenous levels of the auxins. An increase in the biomass of roots and stems of sunflower (Helianthus annuus) plants grown in soil moderately contaminated with lead $(\mathrm{Pb})$ was observed after the addition of the phytohormone IAA [79]. Exogenous supply of IAA also improved the growth of Brassica juncea exposed to As [76]. In the same way, the application of different levels of L-TRP (a precursor of auxin) to the roots of rice seedlings growing in contaminated soil enhanced plant growth and yield under Cd stress, when compared to untreated seedlings in Cd-contaminated pots without this auxin precursor [80]. Some recent approaches showed that this synergistic or additive interaction between heavy metal and auxin can be used as a protective mechanism against toxicity in crop plants or as a useful tool in phytoremediation programs for detoxification of polluted areas. Tandon et al. (2015) [81] evaluate the application of six concentrations of two representative natural auxins (IAA and IBA), and a synthetic auxin (1-Naphthalene acetic acid), in wetland and non-wetland plant species in a 
water environment. The authors showed that exogenous auxin supply increased phytoremediation efficiency in wastewater treatment [33].

The role of IAA application in alleviating the adverse effects of stress factors including heavy metals was also suggested [82]; such as, the decrease in the level of ROS and the increase in seed germination rate, growth and nitrogen metabolism [83]. Exogenous GA3 is also able to overcome the inhibitory effects of different environmental stresses on seed germination and other physiological parameters; such as dry matter contents, chlorophyll, relative water, proline and mineral nutrients, activities of superoxide dismutase, peroxidase and polyphenol oxidase, as well as extent of electrolyte leakage [84]. Another situation was exhibited by this cultivar when its plants were sprayed by IAA. While the amino acids content decreased by $26 \%$ as a result of $\mathrm{H}_{2} \mathrm{O}$ plus IAA treatment, they, on the other hand, increased by about $36 \%$ as a result of $\mathrm{Cu}^{2+}$ plus IAA treatment. The data also revealed that while the concentration of most of the individual amino acids increased as a result of $\mathrm{Cu}^{2+}$ or $\mathrm{Cu}^{2+}$ plus IAA treatments in cv. Assiut 84, the opposite cut held in cv. Assiut 125, where most of the individual amino acids decreased by $\mathrm{Cu}^{2+}$ or $\mathrm{H}_{2} \mathrm{O}$ plus IAA treatments. However, the concentration of most of these individual amino acids increased surprisingly as a result of the interactive effect of $\mathrm{Cu}^{2+}$ and IAA. Amino acids and carboxylic acids such as citrate, malate and histidine are potential ligands for heavy metals and could play a role in tolerance and detoxification. Citrate, malate and oxalate have been involved in transport of metal ions through the xylem and vacuolar sequestering [85]. The significant and proportional change in amino acid or organic acid concentration elicited by a change in metal exposure was shown by histidine response in plants that accumulate nickel [3]. If we take into consideration the concentration of proteins in the pods of the two cultivars at the level of $350 \mathrm{ppm}$ $\mathrm{Cu}^{2+}$, we can notice that: a. In cv. Assiut 84, the high concentration of proteins was corresponding to high concentration of amino acids, compared to the control values, which again recommended the ability of this cultivar to regulate nitrogenous compounds. b. In cv. Assiut 125, it seemed that this cultivar failed to regulate these nitrogenous compounds at the severe dose of copper. Which again recommended the differences in copper tolerance between the two cultivars? The ability to regulate the nitrogenous compounds were considerably recommended when the two broad bean cultivars were treated by IAA at the level of $350 \mathrm{ppm} \mathrm{Cu}^{2+}$ (the great accumulation of both proteins and amino acids). Therefore, it can be concluded that the copper tolerance was closely associated with the up-regulation of nitrogen metabolism. Cultivars variations were also revealed in proline content. The pods of cv. Assiut 84 maintained the proline content mainly around the control value, whatever the treatment used is $\left(\mathrm{Cu}^{2+}\right.$, IAA or $\mathrm{Cu}^{2+}$ plus IAA). On the other hand, and surprisingly, while copper treatment reduced the proline content by about $62 \%$ in relation to the control, the $\mathrm{Cu}^{2+}$ plus IAA treatment elevated the proline content by about $38 \%$. Accordingly, copper played two contrasting effects in the accumulation of proline in 
the pods of the two tested cultivars, an insignificant effect in cv. Assiut 84 and an inhibitory effect in cv. Assiut 125. Copper played two contrasting effects in the accumulation of proline in the pods of the two tested cultivars, an insignificant effect in cv. Assiut 84 and an inhibitory effect in cv. Assiut 125. Interestingly, the same pattern was recorded by IAA, where it induced insignificant changes in cv. Assiut 84 and stimulated the production of proline in cv. Assiut 125. This means that the biosynthesis of proline may be dependent on the cultivars variations rather than the effect of copper or IAA. However, previous results recorded the accumulation of proline in copper-treated crop plants [86]. Backor et al. (2004) [86] reported that proline inhibited metal-induced loss of potassium ion. Our results are in contrast with this observation in cv. Assiut 125, that while copper stimulated the absorption of potassium, it reduced the proline content by more than $60 \%$. Additionally and surprisingly, another situation was observed in cv. Assiut 84, that this cultivar maintained both of them (proline and potassium) mainly around the control. Additionally, there is no correlation in the absorption and accumulation of calcium and magnesium and the criteria of proline in the two selected broad bean cultivars. Accordingly, these confusing results weakened the physiological significance of proline. Zhang et al. (2008) [87] indicated that $\mathrm{Cu}$-responsive proline synthesis is closely related to $\mathrm{NO}$ generation in $C$. reinhardtii, suggesting the regulatory function of $\mathrm{NO}$ in proline metabolism under heavy metal stress. Azooz et al., (2012) [88] support the biphasic effect of copper on Hassawi wheat growth. The stimulatory effect of $\mathrm{Cu}^{2+}$ on the biosynthesis of free amino acids, proline and antioxidant enzyme activities could serve as important components of antioxidative defense mechanism against $\mathrm{Cu}^{2+}$ toxicity. Noreen et al. (2018) [34] showed that application of $400 \mu \mathrm{M}$ copper caused accelerated quantities of proline, protein and calcium.

Therefore, it can be concluded that there are differences in copper tolerance between the two cultivars and their interactions with IAA, it was closely associated with the regulation of nitrogen metabolism, microelement and proline content.

\section{Conflicts of Interest}

The authors declare no conflicts of interest regarding the publication of this paper.

\section{References}

[1] Wuana, R.A. and Okieimen, F.E. (2011) Heavy Metals in Contaminated Soils: A Review of Sources, Chemistry, Risks and Best Available Strategies for Remediation. International Scholarly Research Notices Ecology, 2011, Article ID: 402647. https://www.hindawi.com/journals/isrn/2011/402647/ https://doi.org/10.5402/2011/402647

[2] Gangwar, S., Singh, V.P., Prasad, S.M. and Maurya, J.N. (2011) Differential Responses of Pea Seedlings to Indole Acetic Acid under Manganese Toxicity. Acta Physiologiae Plantarum, 33, 451-462. https://doi.org/10.1007/s11738-010-0565-Z 
https://www.google.com.eg/search?sa=G\&gbv=2\&q=Gangwar, + S., + Sing

[3] Bhatia, N.P., Walsh, K.B. and Baker, A.J.M. (2005) Detection and Quantification of Ligands Involved in Nickel Detoxification in a Herbaceous Ni Hyper Accumulator Stackhousia tryonii Bailey. Journal of Experimental Botany, 56, 1343-1349. https://doi.org/10.1093/jxb/eri135 https://shodhganga.inflibnet.ac.in/jspui/bitstream/.../13/13_references.pdf

[4] Joshi, D., Srivastava, P.C., Dwivedi, R., Pachauri, S.P. and Shukla, A.K. (2015) Chemical Speciation and Suitablity of Soil Extractants for Assessing $\mathrm{Cu}$ Availability to Maize (Zea mays L.) in Acidic Soils. Journal of Soil Science and Plant Nutrition, 15, 1024-1034. https://doi.org/10.4067/S0718-95162015005000071 https://scielo.conicyt.cl/scielo.php?script...95162015000400016

[5] Hamdia, M.A., Mostafa, D. and Al-Hakeem, K.N. (2017) The Combined Action Strategy of Two Stresses, Salinity and $\mathrm{Cu}++$ on Growth, Metabolites and Protein Pattern of Wheat Plant. American Journal of Plant Sciences, 8, 625-643.

https://doi.org/10.4236/ajps.2017.83043

http://www.scirp.org/journal/ajps

[6] Tamez, C., Molina, M.H., Viezcas, J.A. and Torresey, J.L. (2019) Uptake, Transport and Effects of Non-Copper Exposure in Zucchini (Cucuabita pepo). Science of the Total Environment, 665, 100-106. https://doi.org/10.1016/j.scitotenv.2019.02.029

[7] Sharma, A.D., Rathore, S.V.S., Kalyani, S. and Tyagi, R.K. (2014) Comparison of Various Seed Priming Methods for Seed Germination, Seedling Vigour and Fruit Yield in Okra (Abelmoschus esculentus L. Moench). Scientia Horticulturae, 165, 75-81. https://doi.org/10.1016/j.scienta.2013.10.044

https://www.infona.pl/.../bwmeta1.element.elsevier-ea499898-baa9-3dc7-a3f7-b51d $7 \mathrm{e} 5 \mathrm{c} 76 \mathrm{bd}$

[8] Vuksanović, V., Kovačević, B., Katani, M., Orlović, S. and Miladinovi, D. (2017) In Vitro Evaluation of Opper Tolerance and Accumulation in Populusnigra. Archives of Biological Sciences, 69, 679-687. https://doi.org/10.2298/ABS170210014V http://www.serbiosoc.org.rs/arch/index.php/abs/article/view/1463

[9] Summar, A.N., Khan, M.M., Jaskani, M.J. and Kamra, M. (2015) Possible Role of Mucilage in Desiccation and Germination of Citrus Roots Tock Seeds. Pakistan Journal of Agricultural Sciences, 52, 93-96.

https://www.google.com.eg/search?q=roEvaluation+of+Copper+Tolerance+and+A ccumulation+in+Populusnigra.Arch.+Biol.\%2C+Sci.+69\%3A679-687

[10] Mohammad, N., Rengel, Z., Aziz, T., Regmi, B.D. and Saqib, M. (2015) Boron Toxicity Alleviation by Zinc Application in Two Barley Cultivars Differing in Tolerance to Boron Toxicity. Pakistan Journal of Agricultural Sciences, 52, 151-158. https://www.google.com.eg/search?hl=en

[11] Sheng, X.F. and Xia, J.J. (2006) Improvement of Rape (Brassica napus) Plant Growth and Cadmium Uptake by Cadmium-Resistant Bacteria. Chemosphere, 64, 1036-1042. https://doi.org/10.1016/j.chemosphere.2006.01.051 https://www.ncbi.nlm.nih.gov/pubmed/16516946

[12] Egamberdieva, D. (2009) Alleviation of Salt Stress by Plant Growth Regulators and IAA Producing Bacteria in Wheat. Acta Physiologiae Plantarum, 31, 861-864.

[13] Niezyporuk, A.P., Bejauz, A., Szelewa, E.Z. and Bratska, M.C. (2018) Exogenously Applied Auxins and Cytokinins Ameliorate Lead Toxicity by Inducing Antioxidant Defence System in Green Alga Acutodesmus obliquus. Plant Physiology and Biochemistry, 132, 535-546. https://www.ncbi.nlm.nih.gov/pubmed/30316163

[14] Kang, S.-M., Waqas, M., Hamayun, M., Asaf, S., Khan, A.L., Kim, A.-Y., Park, Y.-G. 
and Lee, I.-J. (2017) Gibberellins and Indole-3-Acetic Acid Producing Rhizospheric Bacterium Leifsonia xyli SE134 Mitigates the Adverse Effects of Copper-Mediated Stress on Tomato. Journal of Plant Interactions, 21, 373-380. https://www.tandfonline.com/doi/full/10.1080/17429145.2017.1370142

[15] Hamdia, M.A. (2017) The Briphasic Role of Copper and Counteraction with Azospirillum brasilense Application on Growth, Metabolities, Osmotic Pressure and Mineral of Wheat Plant. American Journal of Plant Sciences, 8, 1182-1195.

https://doi.org/10.4236/ajps.2017.85078

http://www.scirp.org/journal/ajps

[16] Díaz, M.C., Marín, C., Castel, K., Machuca, Á. and AndRifo, S. (2017) Effect of Copper (II) Ions on Morpho-Physiological and Biochemical Variables in Colobanthus quitensis. Journal of Soil Science and Plant Nutrition, 17, 429-440. https://www.google.com.eg/search?hl=en-

[17] Massoud, B.M., Karmous, I., El Ferjani, E. and Chaoui, A. (2018) Alleviation of Copper Toxicity in Germinating Pea Seeds by IAA, GA3, Ca and Citric Acid. Journal of Plant Interactions, 3, 21-29. https://doi.org/10.1080/17429145.2017.1410733 https://www.tandfonline.com/doi/abs/10.1080/17429145.2017.1410733

[18] Rabey, J.M., Vered, Y., Shabtai, H., Graff, E. and Korczyn, A.D. (1992) Improvement of Parkinsonian Features Correlate with High Plasma Levodopa Values after Broad Bean (Vicia faba) Consumption. Journal of Neurology, Neurosurgery, and Psychiatry, 55, 725-727. https://doi.org/10.1136/jnnp.55.8.725 https://www.ncbi.nlm.nih.gov/pubmed/1527547

[19] Elwakil, M.A., El-Refai, I.M., Awadallah, O.A., El-Metwally, M.A. and Mohammed, M.S. (2009) Seed-Borne Pathogens of Faba Bean in Egypt: Detection and Pathogencity. Plant Pathology Journal, 8, 90-97. https://doi.org/10.3923/ppj.2009.90.97 https://scialert.net/abstract/?doi=ppj.2009.90.97

[20] Brady, N.C., and Weil, R.R. (2002) The Nature and Properties of Soil. 13th Edition, Prentice Hall Inc., Upper Saddle River, NJ.

[21] Tibbits, T.W. and Langhans, R.W. (1993) Controlled-Environment Studies. In: Hall, D.O., Scur, R.W., Lock, J.M., Bolhar-Nordenkampf, H.R., Leegoood, R.C. and Long, S.P., Eds., Photosynthesis and Production in a Changing Environment, Chapman \& Hall, London, 65-78.

[22] Fales, F.W. (1951) The Assimilation and Degradation of Carbohydrates of Yeast Cells. Journal of Biological Chemistry, 193, 113-124.

http://www.jbc.org/content/193/1/113.full.pdf

[23] Lowry, O.H., Roserbrough, N.J., Farr, A.L. and Randall, R.J. (1951) Protein Measurementwith the Folin Phenol Reagent. Journal of Biological Chemistry, 193, 265-275. http://en.wikipedia.org/wiki/Journal_of_Biological_Chemistry

[24] Schwarzenbach, G. and Biedermann, W. (1948) Komplexone, X. Erdalkalikomplexe von o, o'-Dioxyazofarbstoffen. Helvetica Chimica Acta, 31, 678-687. https://doi.org/10.1002/hlca.19480310303

[25] Williams, V. and Twin, S. (1960) Flam Photometric Methods for Sodium, Potassiumand Calcium. In: Paech, K. and Tracey, M.V., Eds., Modern Methods of Plant Analysis, Springer-Verlag, Berlin, 3-5. https://en.wikipedia.org/wiki/The_Williams_Brothers

[26] Steel, R.G. and Torrie, J.H. (1960) Principles and Procedures of Statistics. McGraw-Hill Book Co., New York. http://garfield.library.upenn.edu/classics1977/A1977DU23500002.pdf

[27] Bell, P.F., Chaner, R.L. and Angle, J.S. (1991) Free Metal Activity and Total Metal 
Concentrations as Indices of Micronutrient Availability to Barley [Hordeum vulgare

(L.) "Klages"]. Plant and Soil, 130, 51-62.

https://link.springer.com/article/10.1007/BF00011855

https://doi.org/10.1007/BF00011855

[28] Wajid, A., Hussain, A., Ahmed, A., Rafiq, M., Goheer, A.R. and Ibrahim, M. (2004) Effect of Sowing Date and Plant Density on Growth, Light Interception and Yield of Wheat under Semi Arid Condition. International Journal of Agriculture and Biology, 6, 1119-1123.

https://ar.hao123.com/?tn=sdkw_inner_hp_09_hao123_ar\&guid=3db89f20875ee84f $\underline{\text { f03665436790ceb7 }}$

[29] Ivanov, Y.V., Kartashov, A.V., Ivanova, A.I., Savochkin, Y.V. and Kuznetsov, V.V. (2016) Effects of Zinc on Scots Pine (Pinus sylvestris L.) Seedlings Grown in Hydroculture. Plant Physiology and Biochemistry, 102, 1-9.

https://doi.org/10.1016/j.plaphy.2016.02.014

https://www.ncbi.nlm.nih.gov/pubmed/26897114

[30] Hamdia, H.A., Shaddad, M.A.K. and Abd El-Hakeem, N.K. (2018) The Potential Role of Copper and Combined Action with IAA on Tolerance Strategy of Two Broad Bean Cultivars. American Journal of Plant Sciences, 9, 2100-2119.

http://www.scirp.org/journal/ajps https://doi.org/10.4236/ajps.2018.910153

[31] Lu, Y., Yao, H., Shan, D., Jiang, Y., Zhang, S. and Yang, J. (2015) Heavy Metal Residues in Soil and Accumulation in Maize at Long-Term Waste Water Irrigation Area in Tongliao, China. Journal of Chemistry, 2015, Article ID: 628280.

https://www.hindawi.com/journals/jchem/2015/628280/ https://doi.org/10.1155/2015/628280

[32] Mathur, S., Kalaji, H.M. and Jajoo, A. (2016) Investigation of Deleterious Effects of Chromium Phytotoxicity and Photosynthesis in Wheat Plant. Photosynthetica, 54, 185-192. https://link.springer.com/article/10.1007/s11099-016-0198-6 https://doi.org/10.1007/s11099-016-0198-6

[33] Neto, L.B., Paiva, A.L.S., Machado, R.D., Arenhart, R.A. and Pinheiro, M.M. (2017) Interactions between Plant Hormones and Heavy Metals Responses. Genetics and Molecular Biology, 40, 373-386. https://doi.org/10.1590/1678-4685-gmb-2016-0087 https://www.ingentaconnect.com/content/doaj/14154757/2017/00000040/a00101s1/ $\underline{\operatorname{art} 00012}$

[34] Noreen, S., Akhter, M.S., Yaamin, T. and Arfan, M. (2018) The Ameliorative Effects of Exogenously Applied Proline on Physiological and Biochemical Parameters of Wheat (Triticum aestivum L.) Crop under Copper Stress Condition. Plant Environment Interaction, 13, 221-230. https://doi.org/10.1080/17429145.2018.1437480 https://www.tandfonline.com/doi/abs/10.1080/17429145.2018.1437480

[35] Caspar, T.H., Penel, C.L., Greppin, H. and Dommes, J. (2003) Changing Concept in Plant Hormone Action. In Vitro Cellular \& Developmental Biology_Plant, 39, 85-106. https://doi.org/10.1079/IVP2002393 https://www.researchgate.net/publication/225522162

[36] Manchanda, J.S. and Aulakh, M.S. (2011) Impacts of Nitrogen and Micronutrient Interactions on Yield, Quality, and Nutrient Use Efficiency. In: Jain, V. and Ananda Kumar, P., Eds., Nitrogen Use Efficiency in Plants, New India Publishing Agency, New Delhi, India, 157-185.

https://www.researchgate.net/publication/319967913_Impacts_of_nitrogen_and_mi cronutrient_interactions_on_yield_quality_and_nutrient_use_

[37] Iqbal, N., Khan, N.A., Ferrante, A., Trivellini, A., Francini, A. and Kha, M.I.R. (2017) 
Ethylene Role in Plant Growth, Development and Senescence: Interaction with Other Phytohormones. Frontiers in Plant Science, 8, 475.

https://doi.org/10.3389/fpls.2017.00475 https://www.ncbi.nlm.nih.gov/pubmed/28421102

[38] Zho, H., Wu, L., Chai, T., Zhang, Y., Tan, J. and Ma, S. (2012) The Effect of Copper, Anganese and Zin on Plant Growth and Elemental Accumulation in the Manganese-Hyperacumulator Phytolacca americana. Journal of Plant Physiology, 169, 1243-1252. https://doi.org/10.1016/j.jplph.2012.04.016 https://www.ncbi.nlm.nih.gov/pubmed/22796009

[39] Beyer, W.N., Green, C.E., Beyer, M. and Chaney, R.L. (2013) Phytotoxicity of Zinc and Manganese to Seedlings Grown in Soil Contaminated by Zinc Smelting. Environmental Pollution, 179, 167-176. https://doi.org/10.1016/j.envpol.2013.04.013 https://www.academia.edu/12251235/Phytotoxicity_of_zinc_and_manganese_to_se edlings_grown_in_soil_contaminated_by_zinc_smelting

[40] Ebbs, S.D., Bradfield, S.J., Kumar, P., White, J.C., Musante, C. and Ma, X. (2015) Accumulation of Zinc, Copper, or Cerium in Carrot (Daucus carota) Exposed to Metal Oxide Nanoparticles and Metal Ions. Environmental Science: Nano, 3, 114-126. https://doi.org/10.1039/C5EN00161G https://pubs.rsc.org/en/content/articlelanding/2016/en/c5en00161g

[41] Rodriguez, E., Santos, C., Azevedo, R., Moutinho-Pereira, J., Correia, C. and Dias, M.C. (2012) Chromium (VI) Induces Toxicity at Different Photosynthetic Levels in Pea. Plant Physiology and Biochemistry, 53, 94-100.

https://doi.org/10.1016/j.plaphy.2012.01.013 https://www.ncbi.nlm.nih.gov/pubmed/22343752

[42] Mehrizi, M.H., Shariatmadar, H., Khoshgoftarmanesh, A.H. and Dehghani, F. (2012) Copper Effects on Growth, Lipid Peroxidation, and Total Phenolic Content of Rosemary Leaves under Salinity Stress. Agricultural Science and Technology, 14, 205-212.

http://nextoptim.com/script/packcpm.php?csid=1311979\&md=1\&s1=\&stamat $=\mathrm{m} \% 7$ C\%2C\%2Cwiano3IqoGU3BE9GH0dEdHP3xP.667\%2ClEeVSyeuTGYHrI0Bug-Scu7v yue6rL_hxE41kCQEvtnduf-P82ma0YpUEGpc7NI5M28yjvizj0MKdll1yGgjc7XuMpy8 sFljlb4kT0orKMnuPzrlFv1je5C6LqPBoTbqH0CJEnP-oJMNMsgBbZyeSUQ4Zlo-LGd 71PNtA1ymkMol2_M0wWHf5o2cldqgjfZgNloCAl0zdTkM8fZxHHs8luYhzVYAOgy YDqB5ueN3uDeHvzv4ug8Z7gFnDO500ghyy-JDjIk8nWaDZvL_Q9WAYXs0M1fB1b Q9rmgvUqS04DDPNZX8qV4znETurgPUFfWZJHqAC109cYBUjeizwrRBmuAQANq FEg29cnk3PC8yXINQxJLACFM_ixrpNbpFLBg_7GjipWYceWL_VqvGJXRO_qf8tW Zv-jgIXk1pyNN374Y\%2C

[43] Mukhopadhyay, M. and Mondal, T.K. (2015) Effect of Ainc and Boron on Growth and Water Relations of Camellia sinensis (L.) O. Kuntze cv. T-78. National Academy Science Letters, 38, 283-286. https://doi.org/10.1007/s40009-015-0381-5 https://www.infona.pl/.../bwmeta1.element.springer-doi-10_1007-S40009-015-0381-5

[44] Rajkumar, M., Sandhya, S., Prasad, M.N.V. and Freitas, H. (2012) Perspectives of Plant-Associated Microbes in Heavy Metal Phytoremediation. Biotechnology Advances, 30, 1562-1574. https://www.ncbi.nlm.nih.gov/pubmed/22580219 https://doi.org/10.1016/j.biotechadv.2012.04.011

[45] Khan, A.L. and Lee, I.J. (2013) Endophytic Penicillium funiculosum LHL06 Secretes Gibberellin that Reprograms Glycine max L. Growth during Copper Stress. BMC Plant Biology, 13, 86. https://doi.org/10.1186/1471-2229-13-86https://www.ncbi.nlm.nih.gov/pubmed/237 $\underline{21090}$ 
[46] Siddiqui, M.H., Alamri, S.A., Al-Khaishany, M.Y.Y., Al-Qutami, M., Ali, H.M. and Khan, M.N. (2017) Sodium Nitroprusside and Indole Acetic Acid Improve the Tolerance of Tomato Plants to Heat Stress by Protecting against DNA Damage. Journal of Plant Interactions, 12, 177-186.

https://doi.org/10.1080/17429145.2017.1310941 https://www.tandfonline.com/doi/abs/10.1080/17429145.2017.1310941

[47] Oleksyn, J., Karolewski, P., Giertych, M.J., Werner, A., Tjoelker, M.G. and Reich, P.B. (1996) Altered Root Growth and Plant Chemistry of Pinus sylvestris Seedlings Subjected to Aluminum in Nutrient Solution. Trees, 10, 135-144. https://www.google.com.eg/search?sa=G\&gbv=2\&q=..+Oleksyn+J,+Karo

[48] Tani, F.H. and Barrington, S. (2005) Zinc and Copper Uptake by Plants under Two Transpiration Rates. Part I. Wheat (Triticum aestivum L.). Environmental Pollution, 138, 538-547. https://doi.org/10.1016/j.envpol.2004.06.005 https://www.ncbi.nlm.nih.gov/pubmed/16043273

[49] Pätsikkä, E., Kairavuo, M., Sersen, F., Aro, E.-M. and Tyystjärvi, E. (2002) Excess Copper Predisposes 57 Photosystem II to Photoinhibition in Vivo by Outcompeting Iron and Causing Decrease in Leaf Chlorophyll. Plant Physiology, 129, 1359-1367. https://doi.org/10.1104/pp.004788 https://www.ncbi.nlm.nih.gov/pubmed/12114589

[50] Chen, Y., Shi, J., Tian, G., Zheng, S. and Lin, Q. (2004) Fe Deficiency Induces Cu Uptake and Accumulation in Commelina communis. Plant Science, 166, 1371-1377. https://doi.org/10.1016/j.plantsci.2004.01.018

https://www.semanticscholar.org/paper/Fe-deficiency-induces-Cu-uptake-and-accu mulation-in-Chen-Shi/cb9d26295fd61fbda63171b34fea1db40800014b

[51] Yruela, I. (2005) Copper in Plants. Brazilian Journal of Plant Physiology, 17, 145-156. https://doi.org/10.1590/S1677-04202005000100012 https://www.scirp.org/(S(351jmbntvnsjt1aadkposzje))/reference/ReferencesPapers.a spx?ReferenceID $=2135093$

[52] Rombolà, A.D., Gogorcena, Y., Larbi, A., Morales, F., Balde, E., Marangoni, B., Tagliavini, M. and Abadía, J. (2005) Iron Deficiency-Induced Changes in Carbon Fixation and Leaf Elemental Composition of Sugar Beet (Beta vulgaris) Plants. Plant and Soil, 271, 39-45. https://doi.org/10.1007/s11104-004-2001-x http://www.stressphysiology.com/pdf/Rombola_PS_05.pdf

[53] Lombardi, L. and Sebastiani, L. (2005) Copper Toxicity in Prunuscerasifera: Growth and Antioxidant Enzymes Responses of in Vitro Grown Plants. Plant Science, 168, 797-802. https://doi.org/10.1016/j.plantsci.2004.10.012 https://www.researchgate.net/

[54] Panou-Filotheou, H., Bosabalidis, A.M. and Karataglis, S. (2001) Effects of Copper Toxicity on Leaves of Oregano (Origanum vulgare subsp. hirtum). Annals of Botany, 88, 207-214. https://doi.org/10.1006/anbo.2001.1441 https://www.academic.oup.com/aob/article/88/2/207/2587150

[55] Kitagishi, K. and Yamane, I. (1981) Heavy Metal Pollution in Soils of Japan. Japan Science Society Press, Tokyo, 1-302.

[56] Lanaras, T., Moustakas, M., Symeonidis, L., Diamantoglou, S. and Karataglis, S. (1993) Plant Metal Content, Growth Responses and Some Photosynthetic Measurements on Field-Cultivated Wheat Growing on Ore Bodies Enriched in Cu. Physiologia Plantarum, 88, 307-314. https://doi.org/10.1111/j.1399-3054.1993.tb05504.x

[57] Lara, L. and Luca, S. (2005) Copper Toxicity in Prunuscerasifera: Growth and Antioxidant Enzymes Responses of in Vitro Grown Plants. Plant Science, 168, 797-802. 
https://doi.org/10.1016/j.plantsci.2004.10.012

https://www.infona.pl/resource/bwmeta1.element.elsevier-a330aadd-3e44-3ffbb-a65 5-ca34ass6a9c4

[58] Herbik, A., Bölling, C. and Buckhout, T.J. (2002) The Involvement of a Multicopper Oxidase in Iron Uptake by the Green Algae Chlamydomonas reinhardtii. Plant Physiology, 130, 2039-2048. https://doi.org/10.1104/pp.013060 https://www.plantphysiol.org/content/130/4/2039

[59] Morrissey, J. and Guerinot, M.L. (2009) Iron Uptake and Transport in Plants: The Good, the Bad, and the Ionome. Chemical Reviews, 109, 4553-4567.

https://doi.org/10.1021/cr900112r https://www.ncbi.nlm.nih.gov/pubmed/19754138

[60] Yruela, I. (2009) Copper in Plants: Acquisition, Transport and Interactions. Functional Plant Biology, 36, 409-430. https://www.researchgate.net/

[61] Waters, B.M. and Armbrust, L.C. (2013) Optimal Copper Supply Is Required for Normal Plant Iron Deficiency Responses. Plant Signaling \& Behavior, 8, e26611. https://doi.org/10.4161/psb.26611 https://www.researchgate.net/publication/257300875

[62] Bernal, M., Cases, R., Picorel, R. and Yruela, I. (2007) Foliar and Root Cu Supply Affect Differently Fe and Zn Uptake and Photosynthetic Activity in Soybean Plants. Environmental and Experimental Botany, 60, 145-150. https://doi.org/10.1016/j.envexpbot.2006.09.005

[63] Panou-Filotheou, H. and Basabalidis, A.M. (2004) Root Structural Aspects Associated with Copper Toxicity in Oregano (Origanum vulgare subsp. hirtum). Plant Science, 166, 1497-1504. https://doi.org/10.1016/j.plantsci.2004.01.026

[64] Fagrasova, A. (2001) Interactive Effect of Manganese, Molybdenum, Nickel, Copper I and II and Vanadium on the Freshwater Alga Scenedesmus quadricauda. Bulletin of Environmental Contamination and Toxicology, 6, 688-695. https://link.springer.com/article/10.1007\%2Fs001280178

[65] Azeez, M.O., Adesanwo, O.O. and Adepetu, J.A. (2015) Effect of Copper (Cu) Application on Soil Available Nutrients and Uptake. African Journal of Agricultural Research, 10, 359-364. https://doi.org/10.5897/AJAR2014.9010 https://www.researchgate.net/publication/271819466

[66] Yang, Z. and You, J. (2009) Interaction between Aluminum Toxicity and Manganese Toxicity in Soybean (Glycine max). Plant and Soil, 319, 277-289.

https://doi.org/10.1007/s11104-008-9869-9 https://www.researchgate.net/publication/225753292

[67] Rout, G.R., Samantara, P. and Das, P. (2001) Aluminium Toxicity in Plants: A Review. Agronomie, 21, 3-21. https://hal.archives-ouvertes.fr/hal-00886101/document

[68] Mahmood, Q., Rashid, A., Ahmed, S.S. and Bilal, M. (2012) Current Status of Toxic Metals Addition to Environment and Its Consequences. In: Anjum, N., Ahmad, I., Pereira, M., Duarte, A., Umar, S. and Khan, N., Eds., The Plant Family Brassicaceae. Environmental Pollution, Springer, Dordrecht, 35-69.

https://doi.org/10.1007/978-94-007-3913-0_2

https://www.researchgate.net/publication/235246572

[69] Adina, N., Pentea, M. and Butnariu, M. (2015) Mobility of Heavy Metals from Soil in the Two Species of the Aromatic Plants. Revista de Chimie-Bucharest-Original Edition, 66, 382-386.

https://www.google.com.hk/search?q=(2015)+Mobility+of + Heavy+Metals + from + S oil+in+the+Two+Species+of+the+Aromatic+Plants.+Revista+de+Chimie+-Buchar 
est+-Original+Edition, $+66,+382-386 .+$ https://www.scholar.google\&tbm=isch\&sour ce $=$ hp\&sa $=$ X\&ved=2ahUKEwje26ue0-jhAhVLyYUKHSoYC1MQ7Al6BAgFEAs\&bi $\mathrm{w}=1356 \& \mathrm{bih}=632$

[70] Michaud, A.M., Chappellaz, C. and Hinsinger, P. (2008) Copper Phytotoxicity Affects Root Elongation and Iron Nutrition in Durum Wheat (Triticum turgidum durum L.). Plant and Soil, 310, 151-165. https://doi.org/10.1007/s11104-008-9642-0 https://www.researchgate.net/publication/226728215

[71] Fageria, N.K. (2002) Influence of Micronutrients on Dry Matter Yield and Interaction with Other Nutrients in Annual Crops. Pesquisa Agropecuária Brasileira, 37, 1765-1772. https://doi.org/10.1590/S0100-204X2002001200013 https://www.researchgate.net/publication/26350745_

[72] Ahmed, H.H., Khalil, M.K. and AbdEL-Rahman, A.M. (2012) Effect of Zinc, Tryptophan and Indole Acetic Acid on Growth, Yield and Chemical Composition of Valencia Orange Trees. Journal of Applied Sciences Research, 8, 901-914.

https://scholar.cu.edu.eg/?...ahmed1954/.../effect-zinc-tryptophan-and-indole-acetic -acid-growth-yield-and-chemical

[73] Chuan, N.C., Boyce, A.N., Rahman, M. and Abas, M.R. (2016) Effects of Different Soil Amendments on Mixed Heavy Metals Contamination in Vetiver Grass. Bulletin of Environmental Contamination and Toxicology, 97, 695-701.

[74] Fassler, E., Evangelou, M.W., Robinson, B.H. and Schulin, R.(2010) Effects of Indole-3-Acetic Acid (IAA) on Sunflower Growth and Heavy Metal Uptake in Combination with Ethylene Diamine Disuccinic Acid (EDDS). Chemosphere, 80, 901-907. https://doi.org/10.1016/j.chemosphere.2010.04.077 https://www.researchgate.net/publication/44663172_S

[75] Sharma, S.S. and Dietz, K.J. (2006) The Significance of Amino Acid and Amino Acid Dervived Molecules in Plant Response to Heavy Metal Stress. Journal of Experimental Botany, 57, 711-726. https://doi.org/10.1093/jxb/erj073

https://pub.uni-bielefeld.de/record/1600176

[76] Srivastava, S., Chiappetta, A. and Beatrice, M. (2013) Identification and Profiling of Arsenic Stress-Induced microRNAs in Brassica juncea. Journal of Experimental Botany, 64, 303-315. https://doi.org/10.1093/jxb/ers333

http://nextoptim.com/script/packcpm.php?csid=1311979\&md=1\&s1=\&stamat $=\mathrm{m} \% 7$ C\%2C\%2Cwiano3IqoGU3BE9GH0dEdHP3xP.667\%2ClEeVSyeuTGYHrI0Bug-Scu7v yue6rL_hxE41kCQEvtnduf-P82ma0YpUEGpc7NI5M28yjvizj0MKdll1yGgjc7XuMpy8 sFljlb4kT0orKMnuPzrlFv1je5C6LqPBoTbqH0CJEnP-oJMNMsgBbZyeSUQ4Zlo-LGd 71PNtA1ymkMol2_M0wWHf5o2cldqgifZgNloCAl0zdTkM8fZxHHs8luYhzVYAOgy YDqB5ueN3uDeHvzv4ug8Z7gFnDO500ghyy-JDjIk8nWaDZvL_Q9WAYXs0M1fB1b Q9rmgvUqS04DDPNZX8qV4znETurgPUFfWZJHqAC109cYBUjeizwrRBmuAQANq FEg29cnk3PC8yXINQxJLACFM_ixrpNbpFLBg_7GjipWYceWL_VqvGJXRO_qf8tW Zv-jgIXk1pyNN374Y\%2C

[77] Zelinova, V., A.emayehu, A., Bocovas, B. and Tamas, L. (2015) Cadmium-Indued Reactive-Oxygen Species Generation, Canges in Morphogenic Barley Root Tip Are Regulated by Auxin. Biologia, 70, 356-364.

https://doi.org/10.1515/biolog-2015-0035 https://www.degruyter.com/view/j/biolog...70...3/.../biolog-2015-0035.xml

[78] Wan, G., Najeeb, U., Jilani, G., Naeemand, M.S. and Zhou, W. (2011) Calcium Invigorates the Cadmium-Stressed Brassica napus L. Plants by Strengthening Their Photosynthetic System. Environmental Science and Pollution Research, 18, 1478-1486. https://doi.org/10.1007/s11356-011-0509-1 http://repository.uaf.edu.pk/papers.aspx?param=YAR\&id=2011 
[79] Liphadzi, M.S., Kirkham, M.B. and Paulsen, G.M. (2006) Auxin-Enhanced Root Growth for Phytoremediation of Sewage-Sludge Amended Soil. Environmental Technology, 27, 695-704. https://doi.org/10.1080/09593332708618683 https://www.ncbi.nlm.nih.gov/pubmed/16865925

[80] Farooq, H., Asghar, H.N., Khan, M.Y. and Saleem-Mand, Z.A. (2015) Auxin-Mediated Growth of Rice in Cadmium-Contaminated Soil. Turkish Journal of Agriculture and Forestry, 39, 272-276. https://doi.org/10.3906/tar-1405-54 https://www.researchgate.net/publication/271273211

[81] Tandon, S.A., Kumar, R. and Parsana, S. (2015) Auxin Treatment of Wetland and Non-Wetland Plant Species to Enhance Their Phytoremediation Efficiency to Treat Municipal Wastewater. Journal of Scientific \& Industrial Research, 74, 702-707. https://www.researchgate.net/publication/287546866

[82] Chakrabarti, N. and Mukherji, S. (2003) Effect of Phytohormone Pretreatment on Nitrogen Metabolism in Vigna radiate under Salt Stress. Biologia Plantarum, 46, 63-66. https://doi.org/10.1023/A:1022358016487 https://www.researchgate.net/publication/227054829

[83] Karimi, P., Khavari-Nejad, R., Niknam, V., Ghahremaninejad, F. and Najafi, F. (2012) The Effects of Excess Copper on Antioxidative Enzymes, Lipid Peroxidation, Proline, Chlorophyll, and Concentration of $\mathrm{Mn}, \mathrm{Fe}$, and $\mathrm{Cu}$ in Astragalus neo-mobayenii. The Scientific World Journal, 2012, Article ID: 615670. https://doi.org/10.1100/2012/615670 https://www.researchgate.net/publication/233850051

[84] Zhu, X.F., Jiang, T., Wang, Z.W., Lei, G.J., Shi, Y.Z., Li, G.X. and Zheng, S.J. (2012) Gibberellic Acid Alleviates Cadmium Toxicity by Reducing Nitric Oxide Accumulation and Expression of IRT1 in Arabidopsis thaliana. Journal of Hazardous Materials, 239-240, 302-307. https://doi.org/10.1016/j.jhazmat.2012.08.077 https://www.researchgate.net/publication/231611072

[85] Anjum, N.A., Hasanuzzaman, M., Hossain, M.A., Thangave, P., Roychoudhury, A., Gill, S.S., Merlos Rodrigo, V.A., Fujita, M., Kizek, R., Duarte, A., Pereira, E. and Ahmad, I. (2015) Jacks of Metal/Metalloid Chelation Trade in Plants-An Overview. Frontiers in Plant Science, 6, 192. https://doi.org/10.3389/fpls.2015.00192 https://www.ncbi.nlm.nih.gov/pmc/articles/PMC4382971/

[86] Backor, M., Fahselt, D. and Wu, C.T. (2004) Free Proline Content Is Positively Correlated with Copper Tolerance of the Lichen Photobiont Trebouxia erici (Chlorophyta). Plant Science, 167, 151-157. https://doi.org/10.1016/j.plantsci.2004.03.012 http://agris.fao.org/agris-search/search.do?recordID=US201300936432

[87] Zhang, L.P., Mehta S.K., Liu, Z.P. and Yang, Z.M. (2008) Copper-Induced Proline Synthesis Is Associated with Nitric Oxide Generation in Chlamydomonas reinhardtii. Plant and Cell Physiology, 49, 411-419. https://doi.org/10.1093/pcp/pcn017 https://www.ncbi.nlm.nih.gov/pubmed/18252734

[88] Azooz, M.M., Abou-Elhamd, M.F. and Al-Fredan, M.A. (2012) Biphasic Effect of Copper on Growth, Proline, Lipid Peroxidation and Antioxidant Enzyme Activities of wheat (Triticum aestivum cv. Hasaawi) at Early Growing Stage. Australian Journal of Crop Science, 6, 688-694.

https://www.researchgate.net/publication/329486436 